\title{
Lithofacies distribution and sediment dynamics on a storm-dominated shelf from combined photographic, acoustic and sedimentological profiling methods (Bay of Plenty, New Zealand)
}

\author{
Tobias Kulgemeyer ${ }^{\mathrm{a}, *}$, Tilo von Dobeneck ${ }^{\mathrm{a}}$, Hendrik Müller ${ }^{\mathrm{a}}$, Karin R. Bryan ${ }^{\mathrm{b}}$, \\ Willem P. de Lange ${ }^{\mathrm{b}}$, Christopher N. Battershill ${ }^{\mathrm{b}}$ \\ a Faculty of Geosciences and MARUM, Center for Marine Environmental Sciences, University of Bremen, Klagenfurter Straße, 28359 Bremen, Germany \\ b School of Science, University of Waikato, Private Bag 3105, Hamilton, New Zealand
}

\section{A R T I C L E I N F O}

\section{Article history:}

Received 15 July 2015

Received in revised form 10 February 2016

Accepted 8 March 2016

Available online $\mathrm{xxxx}$

\section{Keywords:}

Lithofacies mapping

Sediment transport

Coastal sedimentology

Seafloor photography

Subaquatic dunes

Sorted bedforms

Benthic profiling

\begin{abstract}
A B S T R A C T
Sediment dynamics on a storm-dominated shelf (western Bay of Plenty, New Zealand) were mapped and analyzed using the newly developed multi-sensor benthic profiler MARUM NERIDIS III. An area of $60 \mathrm{~km} \times 7 \mathrm{~km}$ between 2 and $35 \mathrm{~m}$ water depth was surveyed with this bottom-towed sled equipped with a high-resolution camera for continuous close-up seafloor photography and a CTD with connected turbidity sensor. Here we introduce our approach of using this multi-parameter dataset combined with sidescan sonography and sedimentological analyses to create detailed lithofacies and bedform distribution maps and to derive regional sediment transport patterns.

For the assessment of sediment distribution, photographs were classified and their spatial distribution mapped out according to associated acoustic backscatter from a sidescan sonar. This provisional map was used to choose target locations for surficial sediment sampling and subsequent laboratory analysis of grain size distribution and mineralogical composition. Finally, photographic, granulometric and mineralogical facies were combined into a unified lithofacies map and corresponding stratigraphic model. Eight distinct types of lithofacies with seawards increasing grain size were discriminated and interpreted as reworked relict deposits overlain by posttransgressional fluvial sediments.

The dominant transport processes in different water depths were identified based on type and orientation of bedforms, as well as bottom water turbidity and lithofacies distribution. Observed bedforms include subaquatic dunes, coarse sand ribbons and sorted bedforms of varying dimensions, which were interpreted as being initially formed by erosion. Under fair weather conditions, sediment is transported from the northwest towards the southeast by littoral drift. During storm events, a current from the southeast to the northweast is induced which is transporting sediment along the shore in up to $35 \mathrm{~m}$ water depth. Shorewards oriented cross-shore transport is taking place in up to $60 \mathrm{~m}$ water depth and is likewise initiated by storm events.

Our study demonstrates how benthic photographic profiling delivers comprehensive compositional, structural and environmental information, which compares well with results obtained by traditional probing methods, but offers much higher spatial resolution while covering larger areas. Multi-sensor benthic profiling enhances the interpretability of acoustic seafloor mapping techniques and is a rapid and economic approach to seabed and habitat mapping especially in muddy to sandy facies.
\end{abstract}

(c) 2016 Elsevier B.V. All rights reserved.

\section{Introduction}

Coastal regions are the most heavily populated and most dynamic environments on the planet. They are constantly undergoing both natural and man-made changes on time scales from hours (storms,

\footnotetext{
* Corresponding author.

E-mail addresses: tkulgemeyer@uni-bremen.de (T. Kulgemeyer)

dobeneck@uni-bremen.de (T. von Dobeneck), hendrik.mueller@uni-bremen.de (H. Müller), kbryan@waikato.ac.nz (K.R. Bryan), delange@waikato.ac.nz (W.P. de Lange), cbatters@waikato.ac.nz (C.N. Battershill).
}

tsunamis, oil spills) over decades (settlement and coastal engineering projects, coastal erosion) to centuries (climate and sea level change) and longer (subsidence, rifting). A thorough understanding of the processes at work is crucial for the prediction and mitigation of their future development (Gao and Collins, 2014; Schwab et al., 2014; DeFalco et al., 2015). Although in populated regions the shores themselves are often regularly or even permanently monitored, substantial research also has to include the adjacent areas of the inner continental shelf. The composition and distribution of sediment facies (Bradshaw et al., 1994; Hanquiez et al., 2007; Thieler et al., 2014) including shell and mineral enrichments (Frihy, 1994; Badesab et al., 2012; Li et al., 2015) 
as well as morphological features of the seafloor like sorted bedforms (Cacchione and Drake, 1984; Green et al., 2004; Coco et al., 2007; Trembanis and Hume, 2011; DeFalco et al., 2015) and subaquatic dunes or sand ridges (Duane et al., 1972; Swift et al., 1972; Figueiredo et al., 1982; Parker et al., 1982; Bradshaw et al., 1994; Lobo et al., 2000; Simarro et al., 2015) are indicators of hydro- and sediment dynamics of coastal systems.

On wave dominated shelves, sediment transport is controlled by the action of waves in contrast to tides. Storm-dominated shelves are a subset where net sediment transport is mostly driven by high-energy storm waves (Heward, 1981). Most parts of the New Zealand shelf falls under this definition (Carter and Heath, 1975). The study area in the Bay of Plenty (Fig. 1) gained the attention of the international media when a container ship, the MV RENA, ran aground on Astrolabe Reef in October 2011. For the "RENA Long Term Environmental Recovery Monitoring Program" a quick assessment of the state of the seafloor by various bio- and geoscientific studies was necessary (Battershill et al., 2013). This was an opportunity for the first large-scale deployment of the new benthic profiler NERIDIS III (Fig. 2) that was developed at the University of Bremen/MARUM. A survey in November 2012 was initiated by INTERCOAST, a cooperative graduate school of the Universities of Bremen and Waikato.

The main instrument of NERIDIS is an electromagnetic induction coil sensor that measures the magnetic susceptibility and electric conductivity of the surficial sediment down to $\sim 50 \mathrm{~cm}$ giving an insight into the petrology and porosity of the seafloor (Müller et al., 2012). Additional instruments include a digital flash camera system for continuous high-resolution seafloor photography, and a conductivity, temperature and depth probe (CTD) with turbidity sensor. This paper examines the sedimentological environment by analyzing seafloor images and accompanying sidescan sonography as well as sample material that was

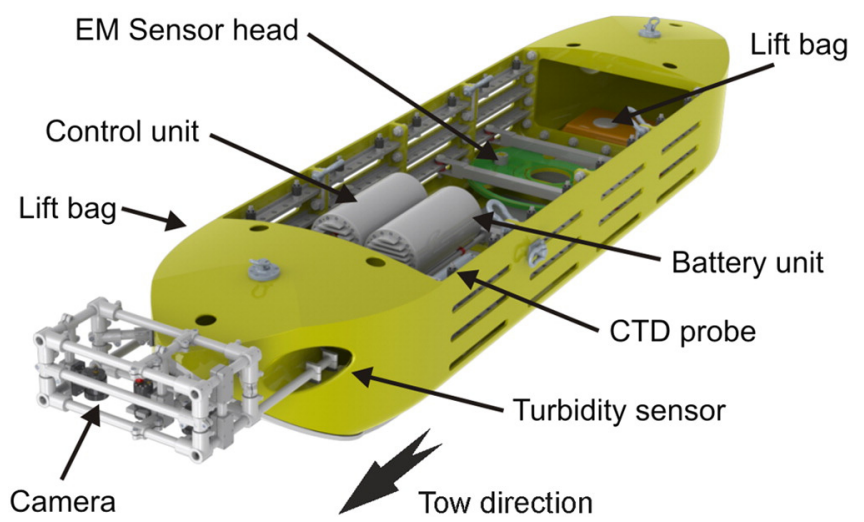

Fig. 2. Schematic view of the benthic profiler NERIDIS III and incorporated systems.

collected during a later survey in December 2013; size and complexity of the electromagnetic data will require a separate publication.

The ability to gain continuous data on large areas has made hydroacoustic methods the standard approach for seafloor mapping (Mayer, 2006). However, the acoustic response of the seafloor is not unique and an accurate interpretation requires ground truthing by independent methods (Barnhardt et al., 1998; Pandian et al., 2009). This is achieved by sampling or by optical examination through videos and still photographs (the latter often in a biological context as it allows the identification of biota and corresponding substrate sediments). Most optical systems are installed in ship-towed platforms or ROVs and operate in a distance of 1-4 $\mathrm{m}$ from the seafloor (Milkov et al., 1999; Rooper and Zimmermann, 2007; Erdey and Cochrane, 2015; Williams et al., 2015). Common classifications

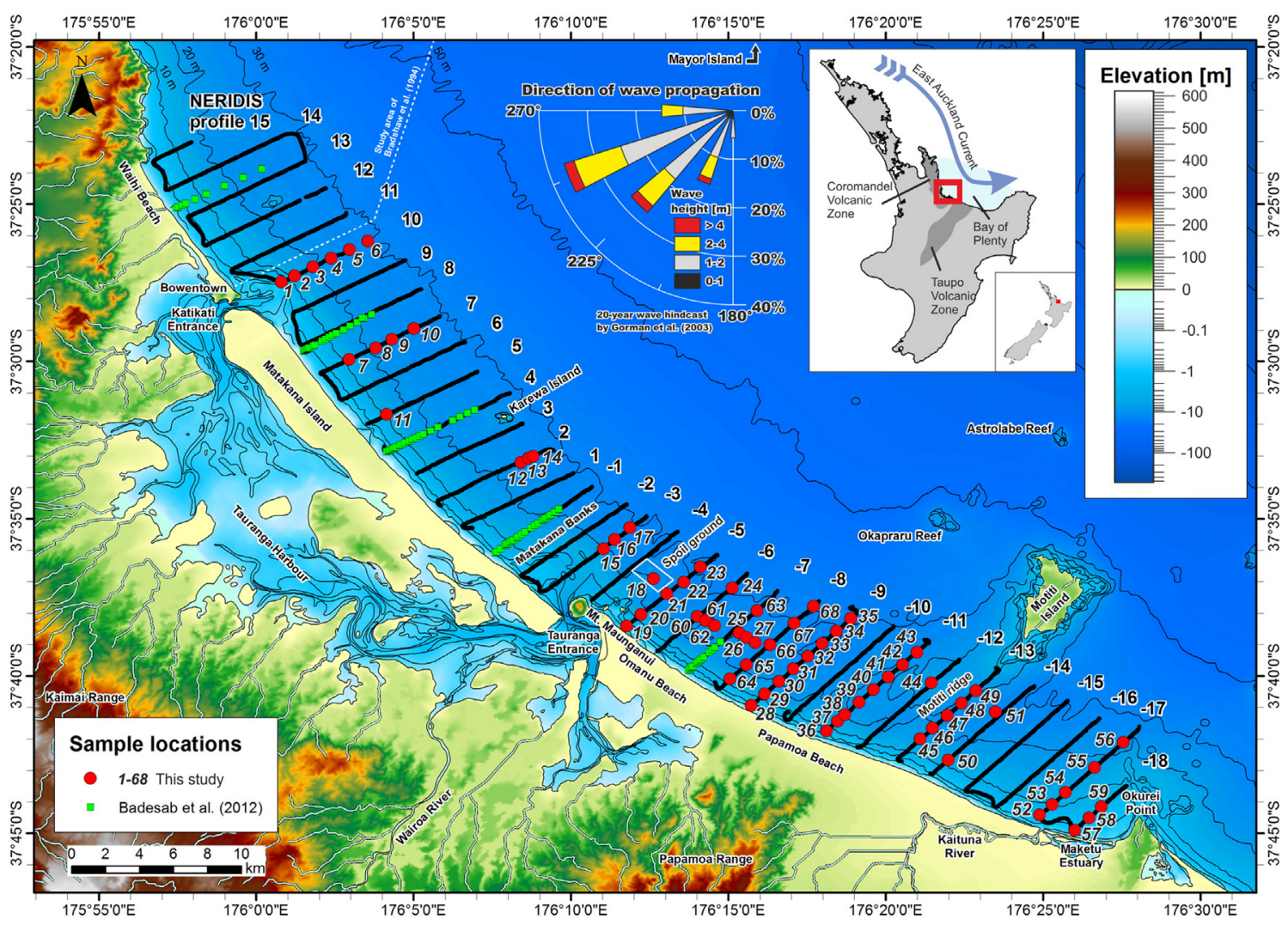

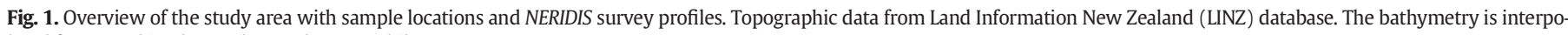
lated from combined LINZ data and own multibeam sonar measurements.

Extent of CVZ and TVZ from Briggs et al. (2005), wave hindcast by Gorman et al. (2003). 
make use of a descriptor (mud, sand, pebble, etc.) and differentiate primary and secondary substrates for a given area (Stein et al., 1992; Yoklavich et al., 2000). In contrast, the camera on board of NERIDIS operates from a ground distance of $40 \mathrm{~cm}$, and the high resolution enables the differentiation of fine, medium and coarse sand. Although close-up seafloor photography has been done in the past (Kostylev et al., 2001), it is mostly punctual. The camera installed on NERIDIS operates with a high frequency and produces a continuous coverage of the profile. As it is rarely used, no standard approach for the classification of this kind of imagery exists so far. The one used here builds on the strengths of high resolution close-up photography. Theoretically, individual grains can be distinguished in sediments larger then medium sand (although practically, motion blur is hindering accurate grain size estimation). This allows for a classification oriented on classical sedimentological methods as they are used e.g. for the description of cores. On this basis, an approach for sedimentological seafloor mapping is developed.

Through this novel multiproxy strategy of geophysical benthic profiling combined with sedimentological laboratory analyses, this study provides insights into bedforms, sediment distribution and transport in a storm-dominated coastal system from the shoreface to the inner shelf. This includes: 1 ) the definition and mapping of sediment facies using combined photographic, hydroacoustic, granulometric and mineralogical evidence; 2) classification and examination of seafloor morphology on the basis of sidescan sonography; 3 ) integration of 1 and 2 together with additional information provided by bottom-water turbidity; and 4) the development of a conceptual sediment transport model.

\section{Study area}

\subsection{Geographic and geological setting}

The Bay of Plenty (BoP) is located on the northern coast of New Zealand's North Island (Fig. 1). It is confined to the east by the East Cape region and to the west by the Coromandel Peninsula. On a regional scale, oceanic water masses in the BoP are subject to the northwestsoutheast flowing East Auckland Current (Brodie, 1960). The study area comprises the coastal region of approximately the western third of the bay and spans $60 \mathrm{~km}$ from the northern end of Waihi Beach to Okurei Point (Town Point) (Fig. 1). The cross-shore extent of the survey area is $7 \mathrm{~km}$ with water depths ranging from 2 to $35 \mathrm{~m}$.

The most prominent landmark of this region is the Tauranga Harbour estuary, a mesotidal lagoon that is shielded from the sea by the barrier island of Matakana (Healy and Kirk, 1982; Healy et al., 1996). The main freshwater input of Tauranga Harbour is Wairoa River (Park, 2004), which transports sediments from rhyolitic source rocks in the Taupo Volcanic Zone (TVZ) northwards into the southern basin (Briggs et al., 2005). The hydrologically independent (De Lange, 1988) northern basin is supplied by smaller local streams draining the Kaimai Ranges, which mark the transition of the older dacitic to andesitic Coromandel Volcanic Zone (CVZ) to the younger TVZ (Briggs et al., 2005). Two entrances north (Katikati Entrance) and south (Tauranga Entrance) of the island connect Tauranga Harbour to the BoP. At both entrances, the side opposite to Matakana is confined by an outcrop of rhyolitic volcanic rock (Briggs et al., 2005) which is connected to the mainland by a narrow tombolo (Healy et al., 1996). In the north, this is the $88 \mathrm{~m}$ high Bowentown dome while in the south the $231 \mathrm{~m} \mathrm{Mt}$. Maunganui is the highest topographic feature. Both domes were formed in association with the TVZ 2-3 Ma ago (Briggs et al., 2005; Cole, 1979). At both entrances, sediment export is driven by ebb-tidal currents (Davies-Colley and Healy, 1978a; Hicks and Hume, 1996, 1997). Sediment exiting Tauranga Entrance forms the ebb-tidal delta of the Matakana Banks. Shell-lag is covering parts of the entrance channel (Krüger and Healy, 2006). A large portion of the sediment is recirculated by a system of tide-induced eddies and returns in a southwesterly direction into the estuary, along with material derived from the inner shelf
(Davies-Colley and Healy, 1978a,b; Spiers et al., 2009). To allow larger vessels to reach the port of Tauranga, the natural ebb tidal delta of Tauranga Entrance has been dredged and deposited in dumping grounds between 4-7 m, 15-25 m and 28-33 m depths offshore Mt. Maunganui (Healy et al., 1991; Davis and Healy, 1993; Foster et al., 1994, 1996, Michels and Healy, 1999).

Another source of sediment for the western BoP are the Maketu estuary and the mouth of Kaituna River at the southeastern end of the study area. The Kaituna derives sediment from nonwelded rhyolitic ignimbrites north of Lake Rotorua and Lake Rotoiti, which originate from the TVZ (Leonard et al., 2010). The river originally discharged into the estuary, but was artificially diverted in 1956 (Burton and Healy, 1985).

The coastline in the western BoP consists of long, sandy beaches. In general, the littoral drift in the study area is directed towards the southeast (Healy, 1977; Healy et al., 1977; Harray and Healy, 1978; Hicks et al., 1999). The northernmost part of the study area at Waihi Beach is prone to erosion (Harray and Healy, 1978; Bear et al., 2009), although onshore transport of sediment has been recorded at the southern end of Waihi Beach (Bear et al., 2009). The $24 \mathrm{~km}$ long barrier island of Matakana has been formed by the building and later convergence of two to three smaller bars during the Holocene on a Pleistocene proto-barrier (Shepherd et al., 1997, 2000). Nowadays the coastline shows little change apart from short-term fluctuations (Gibb, 1994). Omanu and Papamoa Beach are described as in a state of dynamic equilibrium (Iremonger, 2011).

Ten kilometers offshore of the southeastern end of Papamoa Beach is Motiti Island, an andesitic lava dome (Briggs et al., 2005) that was formed between 4.32 Ma and 3.42 Ma (Henry, 1991) and has been eroded down to only a flat remnant.

\subsection{Regional sediment composition}

Bradshaw et al. (1994) provide a general model for Holocene sedimentation on the inner Coromandel shelf directly north of the study area where they describe two main lithofacies groups. The underlying bed of about $5 \mathrm{~cm}$ thickness is an autochthonous deposit (Bradshaw and Nelson, 2004) formed by the erosion of Pleistocene sands during the post-glacial transgression between 12 and $6.5 \mathrm{ka}$. This sediment has a high content of plagioclase (48\%) and quartz (20\%); additional components are lithic fragments (15\%), volcanic glass (8\%) and some heavy minerals (9\%). After sealevel stabilization, these sands were reworked; while their finer fractions moved towards the beach, the coarse fraction remained as lag deposit on the inner shelf. In the late Holocene, the second lithofacies group entered the system when fine and very fine sands were allochthonously delivered from infilled estuaries and started to cover the autochthonous deposits. This overlying bed of less than $5 \mathrm{~m}$ thickness (Bradshaw and Nelson, 2004) is rich in volcanic glass (48\%) and consists otherwise of 31\% plagioclase, 15\% lithic fragments, $9 \%$ quartz and $2 \%$ heavy minerals. For both types of sediment the heavy mineral fraction is made up of hypersthene, opaque minerals, green and brown hornblende, cummingtonite and augite (in decreasing order of percentage).

\subsection{Oceanographic conditions and sediment transport}

The shelf of northeastern New Zealand is generally seen as a stormdominated environment. Tidal currents play only a minor role in the inner shelf dynamics (Bradshaw et al., 1991); an exception in the study area are the entrances to Tauranga Harbour (Spiers et al., 2009). Most wave energy arrives from the open sea from the northeast sector (Pickrill and Mitchell, 1979; Macky et al., 1995; Gorman et al., 2003). Shelf currents in the western BoP have been investigated north of the study area, on the Coromandel shelf (Bradshaw et al., 1991). This system is controlled by two opposing along-shelf currents that develop under different weather conditions: during fair weather, a weak 
southerly directed current is observed, which Bradshaw et al. (1991) linked to the influence of the East Auckland Current (see also Fig. 1). This remotely forced current is a minor component in the local sediment transport regime, most transport occurs cross-shore either by wave action in the surf zone (onshore) or rip currents (offshore) (Bradshaw et al., 1994). Under storm conditions, onshore winds pile up water on the shore. This creates a cross-shore pressure gradient, which initiates a downwelling bottom return flow. In balance with Coriolis forces, this leads to a northerly geostrophic current which transports sediments entrained by wave action in up to $80 \mathrm{~m}$ depth (Bradshaw et al., 1991, 1994). In principle, this bidirectional current regime also acts in the study area. Wave modeling shows that average waves are only capable of entraining sediment in water depths less than $10 \mathrm{~m}$ and transporting it onshore and to the southeast. Sediment in deeper water is only affected by storm waves (Bradshaw et al., 1994; Badesab et al., 2012).

\section{Materials and methods}

\subsection{Benthic profiling}

The benthic profiler NERIDIS III (Fig. 2) was used for an extensive survey of the inner western BoP in November 2012. The system was developed at the MARUM Center for Marine Environmental Sciences, a research institute at the University of Bremen, Germany. It operates as a ship-towed sled and requires ground contact for proper operation. The workboat for the survey was the 14 long aluminium hulled MV MACY GRAY, owned and operated by Western Work Boats Ltd. NERIDIS is $5.2 \times 1.2 \times 0.8 \mathrm{~m}$ in size, and made from non-magnetic, non-conductive materials. Its weight is $900 \mathrm{~kg}$ in air and ca. $250 \mathrm{~kg}$ in water (Baasch et al., 2015).

The profiler's position was determined from the shipboard GPS system by taking the length and angle of the tow cable into consideration. Head, pitch, roll and acceleration were recorded for later correction. With a typical towing speed of 2-4 kn (1-2 m/s) and a capacity of the two internal $40 \mathrm{Ah} 24 \mathrm{~V} / 12 \mathrm{~V}$ lithium ion batteries for 7-12 h operation (depending on the instruments used), one dive between battery changes can cover ca. 50-85 km. The operation was controlled and monitored via a coax link SHDSL.

\subsection{CTD and measurement of turbidity}

The profiler was equipped with a Sea \& Sun Technology CTD 60M multiparameter probe. A connected Seapoint Sensors turbidity sensor monitored the light scattering at $0.5 \mathrm{~m}$ above the seafloor. The acquired data were expressed in Formazine Turbidity Units (FTU) on a limited linear scale from 0 to 25 in 0.001 FTU increments.

\subsection{Seafloor photography}

An AVT Prosilica GC2450C camera system was installed in a downward orientation in the bow of the profiler from where it could take color pictures with a resolution of $1900 \times 1900$ on a $40 \mathrm{~cm} \times 40 \mathrm{~cm}$ area. Pictures were taken with a frequency of $5 \mathrm{~Hz}$ at a towing speed of $2 \mathrm{~m} / \mathrm{s}$ which leads to an overlapping coverage of the seafloor's appearance. Two LED flashlights with $200 \mu$ s flash exposure time on both sides of the camera ensure balanced lighting conditions and avoid motion blur. Overall, about 800,000 photographs of the seafloor were taken. As no automated scheme for the sedimentological evaluation of these photographs has been developed so far, a subset of ca. 6000 photos (one picture every $20 \mathrm{~s} \approx$ every $30 \mathrm{~m}$ ) was analyzed by visual observation.

\subsection{Multibeam and sidescan sonography}

Multibeam bathymetry was continuously recorded during the profiling using by a WASSP WMB-3250 echosounder installed on MV
MACY GRAY. The system operated at a frequency of $160 \mathrm{kHz}$ with a swath width of $120^{\circ} \times 4^{\circ}$.

Acoustic backscatter data was acquired from April to June 2012 by Seaworks Ltd. with an EdgeTech sidescan sonar and covered the entire study area deeper then $10 \mathrm{~m}$. Overlapping lines were surveyed with a separation of ca. $500 \mathrm{~m}$. The data was processed using the software CARIS and later mosaiced into a single map.

\subsection{Sampling}

The sampling campaign took place about one year after the survey using preliminary results for targeting locations. Additional samples collected and studied in early 2010 by Badesab et al. (2012) were added to the sample set. All samples were collected with a Van Veen grab sampler representing the uppermost $1-3 \mathrm{~cm}$ of seafloor.

\subsection{Grain size analysis}

About $4 \mathrm{~g}$ of each sample were dried and treated with $10 \% \mathrm{H}_{2} \mathrm{O}_{2}$ for 8-9 days to remove organic matter. Carbonate was kept in the samples as shell and sponge fragments were in some cases the main sedimentary constituents and, furthermore, to allow direct comparison of physical and visual grain sizes. Volumetric grain size distributions were measured by laser diffraction with a Malvern Instruments Mastersizer 2000 which can measure grains up to $2 \mathrm{~mm}$ in diameter. To prevent large particles from blocking the instrument, all samples were sieved at $1 \mathrm{~mm}$. The sub-millimeter fraction was measured with the laser particle sizer. The coarser fraction was separated again by dry sieving in 1-2 $\mathrm{mm}$ and $\geq 2 \mathrm{~mm}$ fractions. These were weighed and the approximate volume percentage calculated using an estimated density of $2.7 \mathrm{~g} / \mathrm{cm}^{3}$. For a general classification of sediments, a slight error in the smallest fractions due to the presence of iron oxides can be neglected. The obtained data was analyzed with the software GRADISTAT from Blott and Pye (2001).

\subsection{Mineralogical analysis}

Sediments were micro-optically analyzed with a Zeiss Stemi 2000 binocular. As far as possible, minerals were identified based on color, luster and morphology. Also, the quantity of mafic (dark) minerals was estimated using reference charts. Additionally, some X-ray powder diffractometry was performed with a PANalytical Empyrean diffractometer equipped with a copper tube as radiation source where 2-Theta ranged from $10^{\circ}$ to $80^{\circ}$ in increments of 0.02 . These data was examined using the PANalytical HighScore software with the PDF-2 database as reference.

\section{Strategies and principles of investigation}

The general scheme used for the lithofacies classification is outlined on the left side of Fig. 3: first, sediments were classified based on their photographic appearance ("photofacies"). Wherever possible, the respective facies boundaries were determined by associated acoustic backscatter data. However, this approach is not suitable for distinguishing adjacent facies of similar grain size. Where bedforms were observed between profiles, boundaries were drawn so that a single bedform was completely enclosed within one photofacies. Sampling stations were chosen according to the photofacies, and with consideration of existing samples from Badesab et al. (2012). From the samples, a mineralogical and a grain size related classification was created. In the second step, these mineral-, granu- and photofacies were combined into a single lithofacies scheme. The spatial extent was again based on the existing boundaries of the photographic facies map; final adjustments according to the methodology above were made if necessary.

The lithofacies map is one of the required inputs for the development of a conceptual sediment transport model as seen on the right 


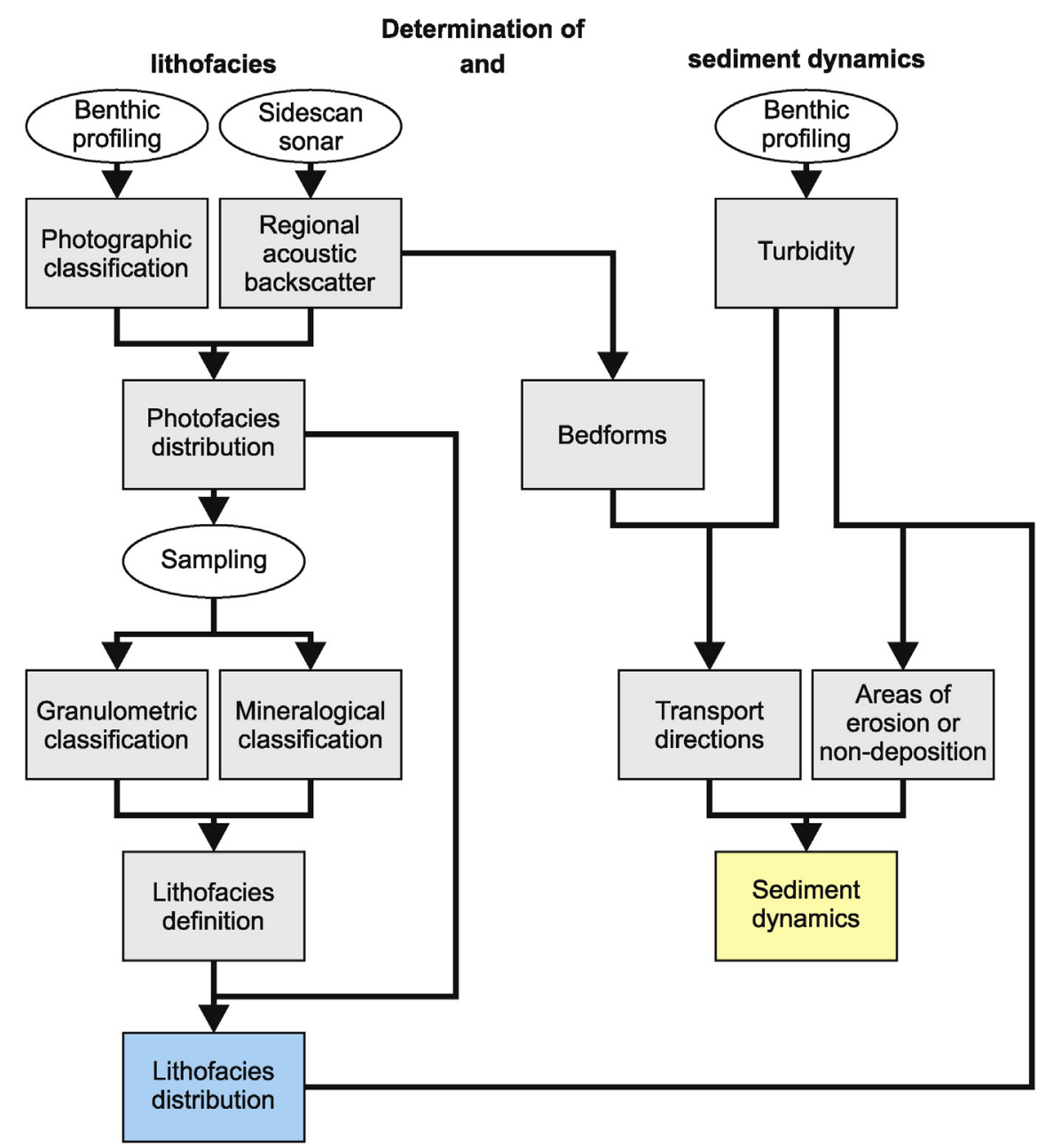

Fig. 3. Classification scheme for the definition and mapping of the lithofacies and the deduction of sediment dynamics (explained in text, Section 4).

side of Fig. 3. Along with turbidity, it allows us to delineate erosive and non-depositional environments. Transport directions can be derived from the examination of the type and orientation of bedforms based on their acoustic backscatter patterns; turbidity provides some additional insight into these processes. The information about the apparent sediment dynamics and direction of sediment transport are combined into a final conceptual model.

\subsection{Photographic sediment classification}

Three parameters were taken into account for the definition of photographic facies: color according to the Munsell color chart, apparent grain size and apparent composition. For an optical estimate of the grain size, an area of $1 \mathrm{~cm}^{2}$ was selected in a representative image and every apparent grain marked by a rectangle. Following Fernlund (2005), the underlying assumption is that particles in the image are lying in a stable position and the visible part is close to the maximum projected area of the grain. In this position, the long side of the minimum bounding rectangle represents the long axis and the short side the intermediate axis of the particle (the short axis would be perpendicular to both). For an overall classification of grain size as fine to very coarse sand, the median of the intermediate axis (rounded to $10 \mu \mathrm{m}$ ) were used.

\subsection{Mineralogical sediment classification}

The mineralogical classification was based on microscopic optical observation referring to literature on the adjacent coastal areas
(Bradshaw et al., 1994) and regional terrestrial geology (Ewart, 1965). Supporting XRD scans were performed on an instrument equipped with a $\mathrm{Cu}$ anode; this is problematic as $\mathrm{Cu}$ radiation leads to fluorescence in Fe which results in a high background level. It was also difficult to properly grind the samples with the available equipment. As a result, only quartz and plagioclase could clearly be identified while most of the mafic phases were either below the limit of detection or show distorted diffraction patterns.

However, the presence and a rough estimation of the amount of amorphous phases in the sample (probably volcanic glass) was deliverable with the technique. Although amorphous phases do not diffract radiation in a specific pattern, they lead to a characteristic increase of background radiation ("glass bulge") between a $2-\theta$ of about $10^{\circ}$ and $30^{\circ}$ (Zevin et al., 1995). The appearance of this bulge has been used to determine which samples contain glass. If it has been observed, we assume that the amount of glass in the sample is relatively high; Pawlowski (1985) gives 40\% (weight) as the minimal detectable amount of volcanic glass.

\subsection{Granulometric sediment classification}

The grouping of sediment samples based on grain size distributions was accomplished in three steps: the first step was a broad classification according to the median grain size into fine, medium and coarse or very coarse sand. The second step accounted for the position of the main mode and, if necessary, a third step was conducted to find the position of a secondary mode. The second and third sorting steps were based on the far more detailed sub-millimeter distribution curves for fine 
and medium sand, whereas the complete distribution curves were used for coarse and very coarse sand.

\subsection{Definition of bedforms}

Bedforms were identified based on characteristic shapes and include coarse grain bands or patches, sorted bedforms as well as subaquatic dunes. Dunes were identified as elongated areas of high backscatter located next to a more or less strongly developed zone of low backscatter or acoustic shadow. The width (meaning the extension parallel to the crest/trough) and strike angle of each dune were measured in ArcGIS.

The defining characteristic of sorted bedforms is the grain size gradient in long-shore direction, where coarser grains are located at the up-current side (but not necessarily confined to the bathymetric low point (Murray and Thieler, 2004) and form a sharp contrast to the surrounding finer grained sediments (Stark et al., 2012). The down-current side is usually more diffuse and can take the form of a series of "fingers" extending from the main bedform (Spiers and Healy, 2007).

\subsection{Interpolation and gridding of NERIDIS data}

Turbidity data obtained by benthic profiling with NERIDIS were interpolated in ArcGIS via Universal Kriging. The dataset was not interpolated entirely as a whole but instead was divided into 10 overlapping areas which contain 4-5 profiles each. Thereby, Kriging parameters could be adapted by automatic as well as manual settings to each environment in a way that is physically reasonable and minimizes statistical errors.

\section{Results and initial classifications}

To facilitate comprehension different terms have been used in the photographic, mineralogical and granulometrical facies classification: "photofacies" for the visual appearance, "type" for mineral composition and "group" for grain size distribution.

\subsection{Photographic facies}

The photographic sediment classification led to the differentiation of six different classes (examples shown in Fig. 4, spatial distribution in Fig. 5). Due to technical problems, no photographs are available between profiles -6 and -8 . Furthermore, large amounts of lea lettuce (Ulva spp.) covering the camera lens on profiles -2 and -3 made most of the photographs unsuitable for interpretation.

- Photofacies 1 is a grayish black (Munsell color N2) sand with an optical grain size in the medium sand fraction $(400 \mu \mathrm{m})$. This photofacies occurs in water depths of 5-20 m. Close to the shoreline ripples are abundant as well as settlement by sand dollars, a species of echinoderms related to sea urchins. Occasionally bivalves occur within facies 1 , but shells and shell fragment only make up a minor fraction of the sediment composition. Close to the southern entrance to Tauranga Harbour this sediment is covered with sea lettuce.

- Photofacies 2 has a similar grayish black (N2) color, but larger optical grain size than photofacies 1 (medium to coarse sand, $500 \mu \mathrm{m}$ ) and appears to be less well sorted. It is mostly found at 15-25 m water depth and commonly contains shell material.

- Photofacies 3 has a greenish black color (5GY 2/1) and a visual grain size of coarse sand $(700 \mu \mathrm{m})$. This photofacies contains some very dark to completely black grains and often large amounts of shell material.

- Photofacies 4 is a visually coarse to very coarse sand (1000 $\mu \mathrm{m})$. This sediment is made up of medium dark gray (N4) as well as light olive (10Y 5/4) particles, most likely due to a large amounts of shell material. Photofacies 4 has only been observed on two distant locations in the study area, in front of the northern entrance to Tauranga Harbour and at the Maketu estuary. The variant in the southeast appears associated with black sand, but these two types of sediment are not homogeneously mixed. Instead the black sand usually forms distinct dark deposits elongated parallel or at an angle up to $45^{\circ}$ to the coastline within the light surrounding sediment. This feature is not present at the northern entrance.

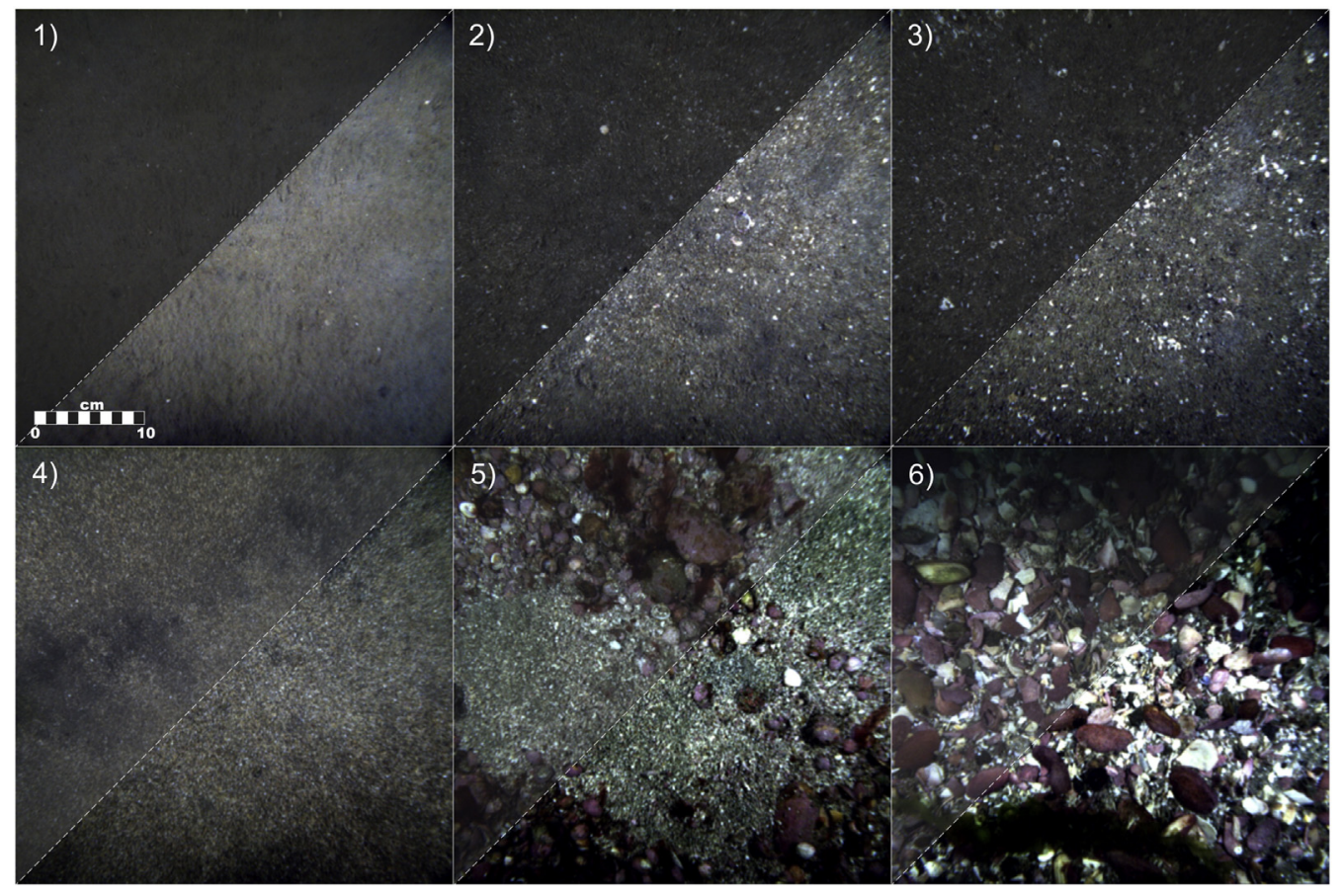

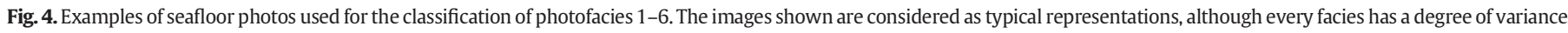

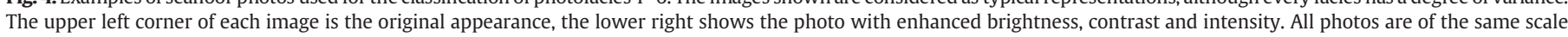
$(40 \times 40 \mathrm{~cm})$. 


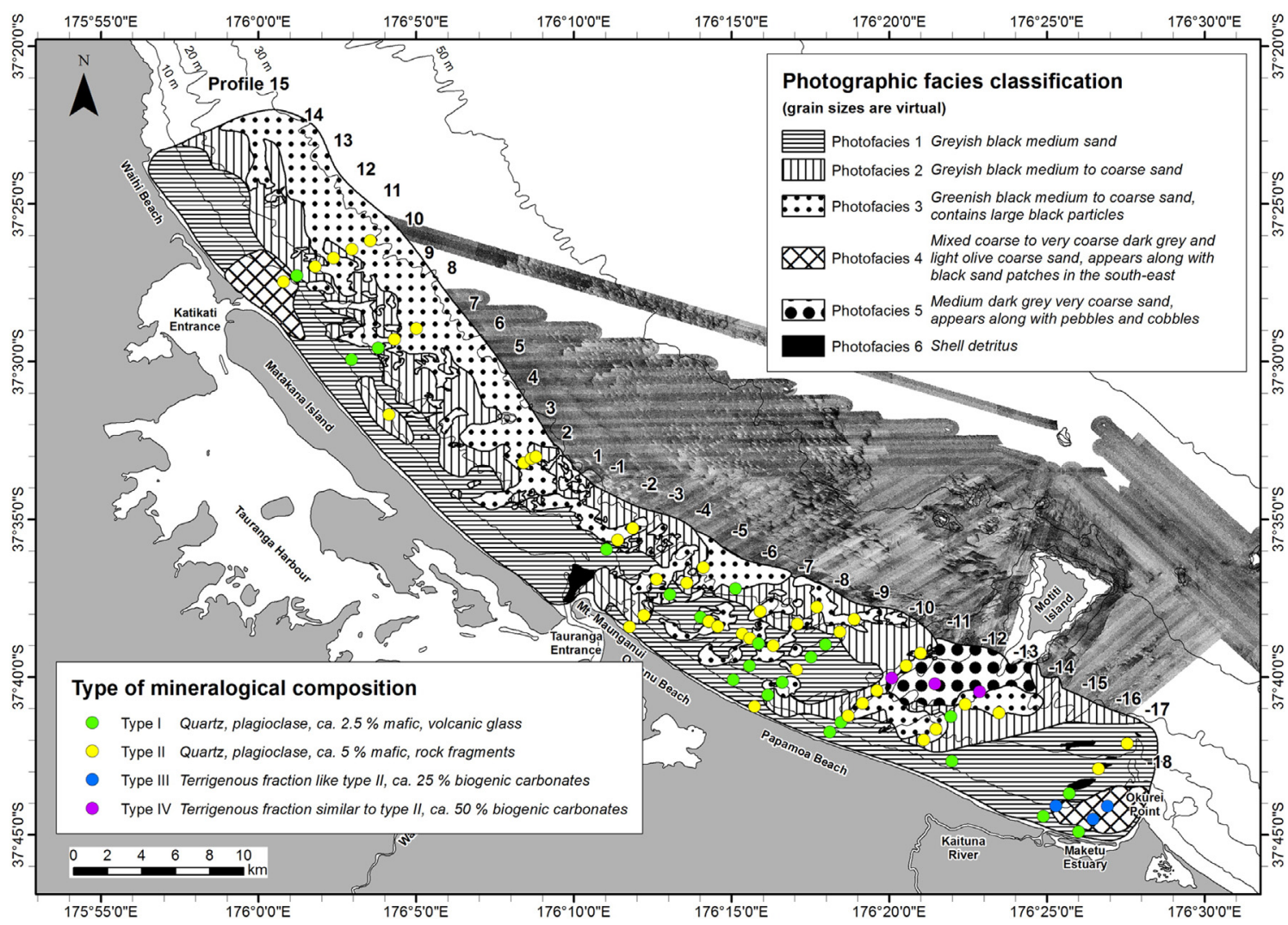

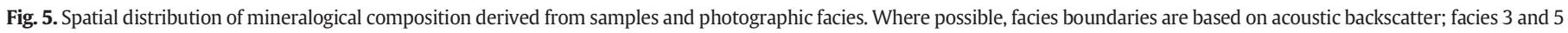

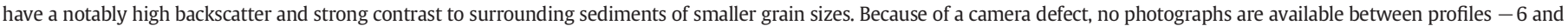
-8 ; due to their high backscatter, sorted bedforms in this area have been marked as photofacies 3 .

- Photofacies 5 occurs only southwest of Motiti Island and is clearly connected to the island itself. It is mostly made up of visually very coarse sand $(1150 \mu \mathrm{m})$, that appears alongside larger clasts (pebbles and larger). The sediment has a medium dark gray (N4) color and is frequently densely colonized by diverse biota including sea lettuce (Ulva spp.) and several species of bivalves.

- Photofacies 6 is not a distinct sediment photofacies but describes areas where the seafloor is mostly covered with shells. This mainly occurs directly inside the southern entrance to Tauranga Harbour, but also on smaller, isolated patches south east of Motiti Island. While the former is made up of very large unbroken shells, the deposit in the southeast contains mostly fragments and some small unbroken shells.

\subsection{Mineralogical facies}

Based on their mineralogical facies, sediments have been classified in four types of compositions. Due to problems regarding XRD data, the definition of these types is mostly based on optical examination. Their spatial distribution is displayed in Fig. 5.

- Type I consists mostly of white or transparent minerals with glassy luster, either quartz or plagioclase feldspar. The sphericity of grains makes it difficult to differentiate based on cleavage. Mafic minerals make up about $2.5 \%$ of the entire assemblage. They are mostly prismatic, occasionally bladed and in some isolated cases, hexagonal and platy. Colors are black and dark green. In accordance with regional geology, they can be interpreted as pyroxene and hornblende, while the platy minerals are likely to be biotite. Additional components are irregularly shaped, transparent particles with very sharp edges; these are probably glass shards (see Bradshaw et al., 1994). This interpretation is supported by the existence of the typical glass "bulge" in the diffractogram of 15 out of the 21 samples belonging to this type. The very fine fraction of this type of sediment gives it an overall "dusty" appearance.

- Type II The mafic fraction is more prominent in this type of sediment. It comprises about $5 \%$ of all minerals, which are not only black but also brown in color. These are again identified as mostly pyroxene and hornblende; biotite has not been found. In addition to single phases, this type also contains rock fragments. Glass shards could not be identified optically, although the shape of the diffractogram indicates an amorphous phase in 7 out of 41 samples. These seven samples belong to the more fine grained examples of type II and have a similar "dusty" appearance to type I.

- Type III appears to be similar in composition to type II, but is mixed with a large amount of shell material (estimated around 25\%). Macroscopically this leads to an easily recognized brownish color.

- Type IV is set apart from other sediment by its large amount of shell, sponge and other organic carbonate fragments (ca. 50\%). Terrestrial components seem to be similar to type II, including rock fragments. Mafic minerals, although negligible when the overall composition of the sediment is concerned, make up slightly more than $5 \%$ of terrestrial components. A pebble-sized rock fragment is part of the sample and is consistent with this estimate. A petrographic analysis has not been conducted for this single piece, but judging from the outer appearance, it is made of andesite (which is to be expected given the proximity to Motiti Island).

\subsection{Granulometrical facies}

The classification of the granulometrical facies comprises of six distinct groups (Fig. 6). Median grain sizes range from $132 \mu \mathrm{m}$ to $919 \mu \mathrm{m}$. The spatial distribution map shows that the majority of the coarser 


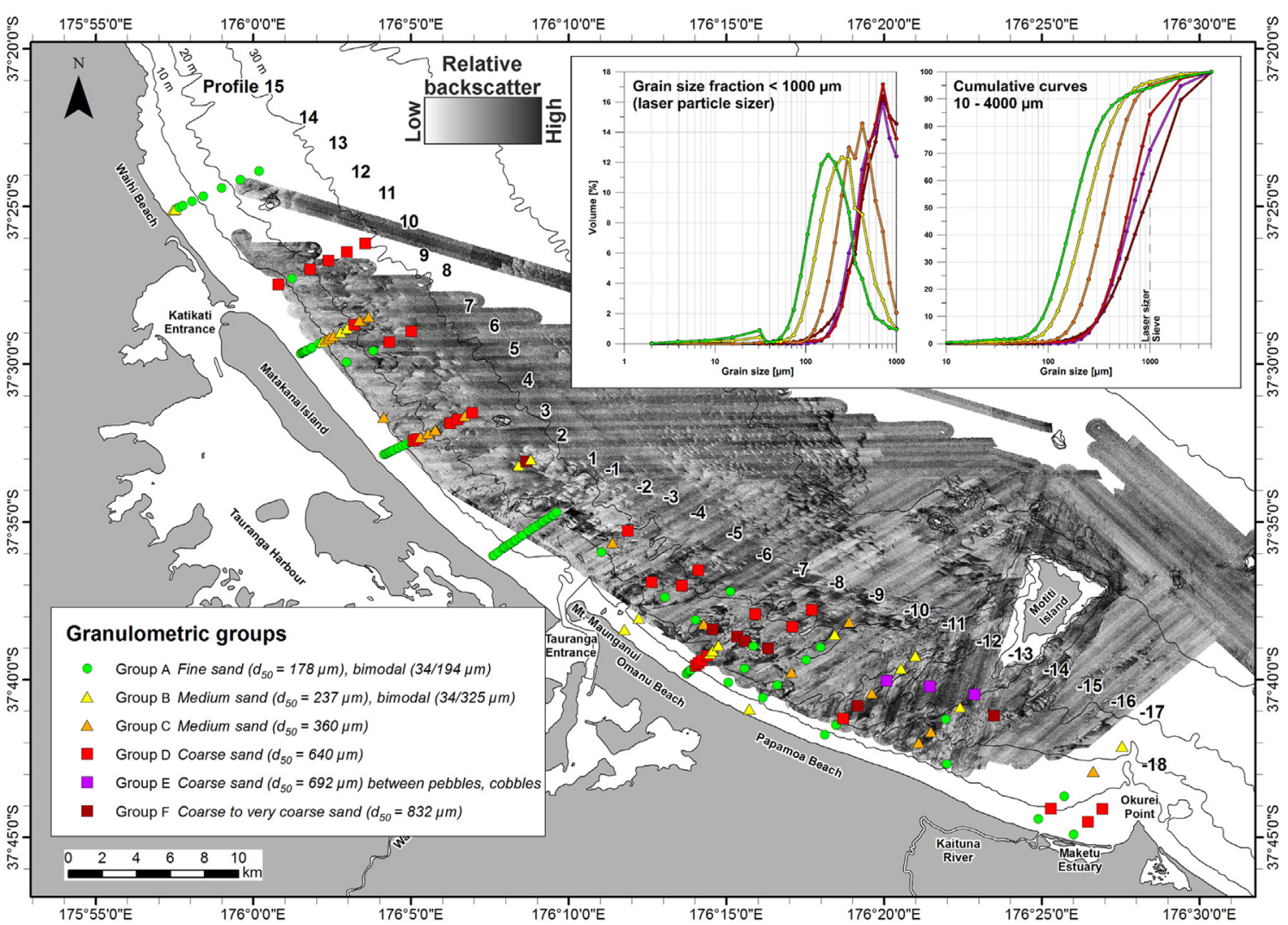

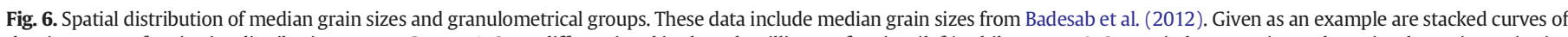

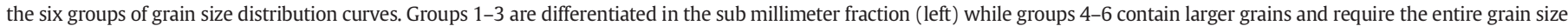
spectrum.

grains are concentrated southwest of Motiti Island and as part of sorted bedforms in the area along Omanu Beach. Additional locations are close to the Maketu Estuary and the northern entrance to Tauranga Harbor. Furthermore, a gradient from fine to coarse grains exists with growing distance from the shore, which is consistent with observations from earlier studies in the BoP (Bradshaw et al., 1994; Badesab et al., 2012).

- Group A is a bimodal fine sand. The median grain size is $178 \mu \mathrm{m}$ and the main mode is at $194 \mu \mathrm{m}$. A small secondary mode (ca. 1\% of particles) is positioned at $34 \mu \mathrm{m}$. Sediments of this group are found in the entire study area in a water depth of up to $20 \mathrm{~m}$, at Omanu Beach they even reach $30 \mathrm{~m}$. The distribution of this group is for the most part identical to photofacies 1 .

- Group B is a medium sand $\left(d_{50}=237 \mu \mathrm{m}\right)$ with a slight bimodal distribution. The main mode is at $325 \mu \mathrm{m}$, the second mode is located at the same grain size as in group A $(34 \mu \mathrm{m})$, but is much less pronounced (ca. 0.5\%). Group B sediments appear to make up the largest portion of photofacies 2.

- Group C is a medium sand with median grain size of $360 \mu \mathrm{m}$. The mode of this distribution is often split into two almost equally high maxima at 325 and $460 \mu \mathrm{m}$ with only a slight decrease between, but this form does not appear distinctive enough to constitute true bimodality.

- Group D, a unimodal coarse sand, is often encountered in the western BoP. The closest it has been found to the beach is at Maketu Estuary in a depth of $6 \mathrm{~m}$; otherwise it appears to be more widespread in the deeper parts of the study area (below $20 \mathrm{~m}$ ). It has a $d_{50}$ of $640 \mu \mathrm{m}$ and a mode of $750 \mu \mathrm{m}$. This group encompasses most of photofacies 3 and 4 .

- Group E cannot be easily distinguished from group D by the distribution curve alone. The median grain size is $692 \mu \mathrm{m}$ and the mode is again at $750 \mu \mathrm{m}$. However, this sediment contains some particles that are even coarser than the $4 \mathrm{~mm}$ limit that was used for the distribution curves. The largest of these is a pebble with a diameter of $3 \mathrm{~cm}$. Sediments of this group are identical to the mineralogical type IV and photographic facies 5.

- Group F is similar to group D, but contains a larger portion of coarser grains. The median grain size is considerably higher $-832 \mu \mathrm{m}-$ and although the sole mode is also located at $750 \mu \mathrm{m}$, it is much less pronounced than in group $\mathrm{D}$. This group also contains the coarsest sediment that was found during the sampling campaign: a very coarse sand from the center of a sorted bedform between profiles -7 and -8 .

\subsection{Backscatter and bedforms}

Regional acoustic backscatter generally increases towards the southeast. A particularly high backscatter can be observed on the ridge southwest of Motiti Island. Another noteworthy location is north of Tauranga Entrance, where the otherwise very weak backscatter is interrupted by a structure with extremely high values below the $20 \mathrm{~m}$ isobath.

Sand patches and ribbons were found either as singular features or coupled with large, shore-normal striking dunes. In most cases, these features have a higher acoustic backscatter than the surrounding sediments, thus indicating coarser grain sizes. They are almost always oriented parallel to the coastline. On some occasions a single bedform bifurcates into a pattern of multiple bands (Fig. 7a). In every observed case the bifurcation was oriented so that the scale decreased towards the northwest. Of special interest are long and very thin coarse sand ribbons south-southeast of Motiti Island in 20-25 m water depth (Fig. 7c). They extend perpendicular to the mainland coast and parallel to the extent of the submarine ridge. The adjacent area also shows high and low 

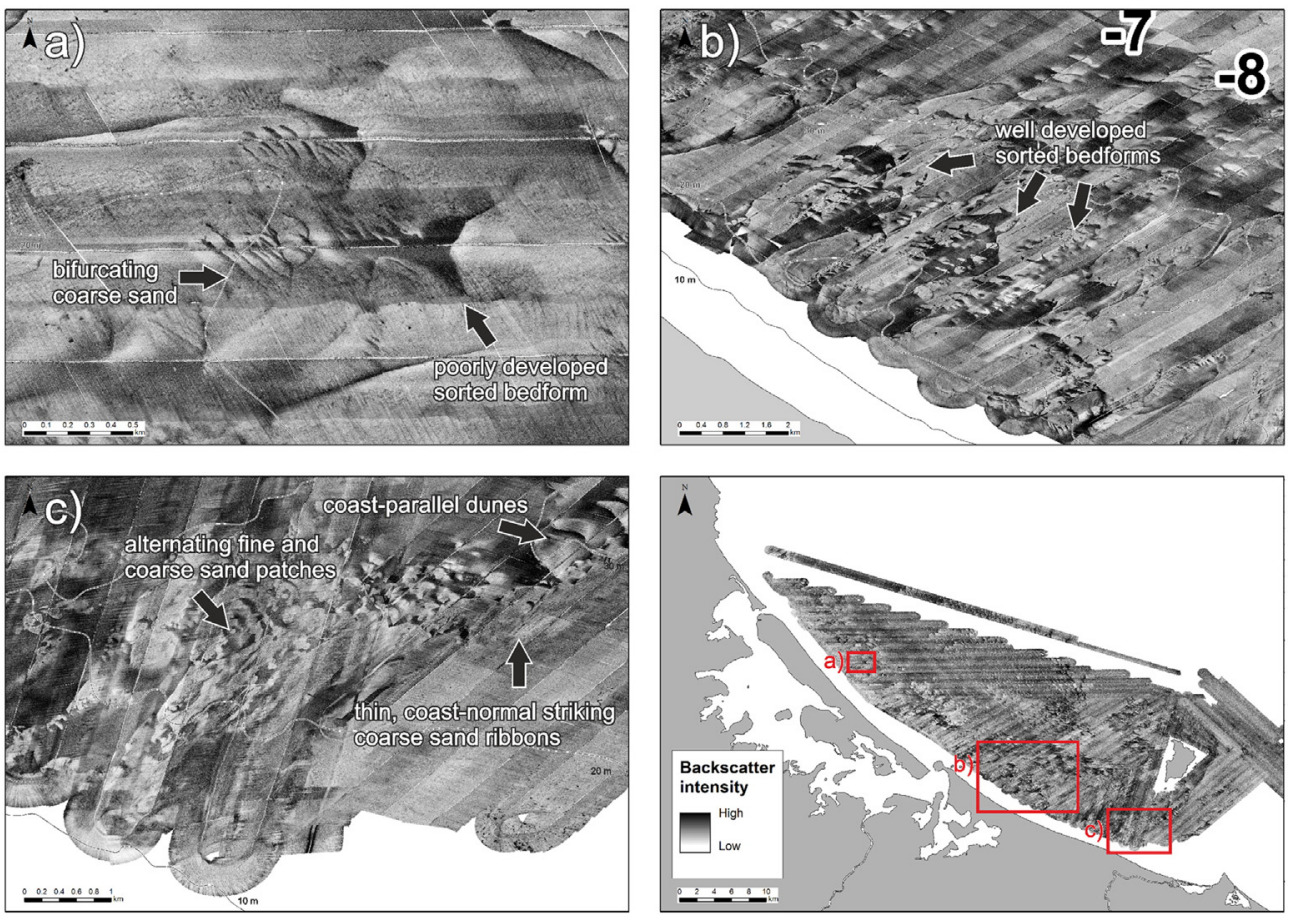

Fig. 7. Examples of bedforms in the study area. These include coarse sand patches and ribbons as well as sorted bedforms of various dimensions and distinctiveness.

backscatter features alternating without one of them being clearly dominant. These features are concentrated in a bathymetric depression and follow the steepest gradient towards the $30 \mathrm{~m}$ isobath. Below this point, the sand ribbons disappear and instead a series of shore-parallel dunes is observed.

Sorted bedforms (500-650 m cross-shore, 200-300 m long-shore) were found along the coast of Matakana Island (Fig. 7a). These structures are relatively poorly developed; the shape is not as distinctive and the boundaries not as sharp as described in literature. They strike perpendicular or at a slight angle to the coast and are oriented with the more diffuse end towards the northwest. Well developed sorted bedforms could be identified offshore of Omanu Beach. They extend perpendicular to the shoreline from southwest to northeast and stand out from their surroundings by a very high acoustic backscatter (Fig. 7b). The structures are approximately $1 \mathrm{~km}$ long-shore and $2.5 \mathrm{~km}$ cross-shore. While their southeastern boundaries are abrupt with very strong backscatter, the northwestern limits have a "feathered-out" appearance. Unfortunately, only few shoreparallel profiles were recorded, and only the shoreward end of one of the bedforms has been covered by the ship's multibeam sonar. While this is not sufficient for conclusive observations, it appears that the bedforms coincide with slight depressions of the seafloor and the strongest backscatter occurs on their lowest point.

Subaquatic dunes are marked by a line parallel to their strike. While the region between 10 and $30 \mathrm{~m}$ water depth is densely covered in dunes, almost no bedforms could be found between 35 and $40 \mathrm{~m}$ depth. However, a large dune field is again located between 40 and $55 \mathrm{~m}$. The majority of these deep-water bedforms strike parallel to the coast of the mainland. With decreasing distance to the shore, the angle changes to a more shore-normal orientation and dune width (meaning the extent parallel to the crest) increases. Towards the southeast, the strike angle changes and dunes become aligned parallel to the coast of Motiti Island (Fig. 8).

\subsection{Turbidity}

The turbidity of bottom water spans a wide range from 0.027 to 24.744 FTU, but the distribution is strongly right-skewed. With a median of 0.508 , values higher than ca. 1 are confined to only a narrow section close to the beach where the water depth is less than $5 \mathrm{~m}$. The only places where a turbidity in the higher range was measured was directly at Katikati Entrance and northwest of Tauranga Entrance (profile -3 to 2). The section along Omanu and Papamoa beach has a relatively low turbidity compared to similar water depths along the Matakana coastline. This only changes again east of the submarine ridge between Motiti and the mainland coast.

According to the records of the National Institute of Water and Atmospheric Research (NIWA), the weather conditions were stable over the duration of the NERIDIS survey. A part of profile -3 had to be removed from the dataset, in this case turbidity exceeded the sensor range which was probably the result of sea lettuce coverage on the profiler (see Fig. 9).

\section{Discussion}

\subsection{Seafloor mapping}

While other optical techniques that make use of images taken from a larger ground distance allow a good qualitative assessment of changing seafloor coverage especially of heterogeneous areas (Stein et al., 1992; Yoklavich et al., 2000; Rooper and Zimmermann, 2007; Erdey and Cochrane, 2015), close-ups enable a more detailed look on small-scale characteristics. Despite some limitations, the facies determined from close-up seafloor photography are remarkably similar to those based on sedimentological evidence.

The physical properties of sediment as determined from samples fit generally well to the initial frame provided by optical appearance. This is especially clear for grain sizes, the major criterion for the definition of photofacies. However, grain sizes detectable from photographs are considerably coarser than those measured from sample material. The optical examination of grain sizes is limited by resolution and noise level of the photographs, motion blur due to the movement of the profiler and a lack of contrast between overlapping grains of similar color, which can often not properly be distinguished from each other. As a result, there is a bias towards the largest particles or aggregates. 
T. Kulgemeyer et al. / Marine Geology xxx (2016) xxx-xxx

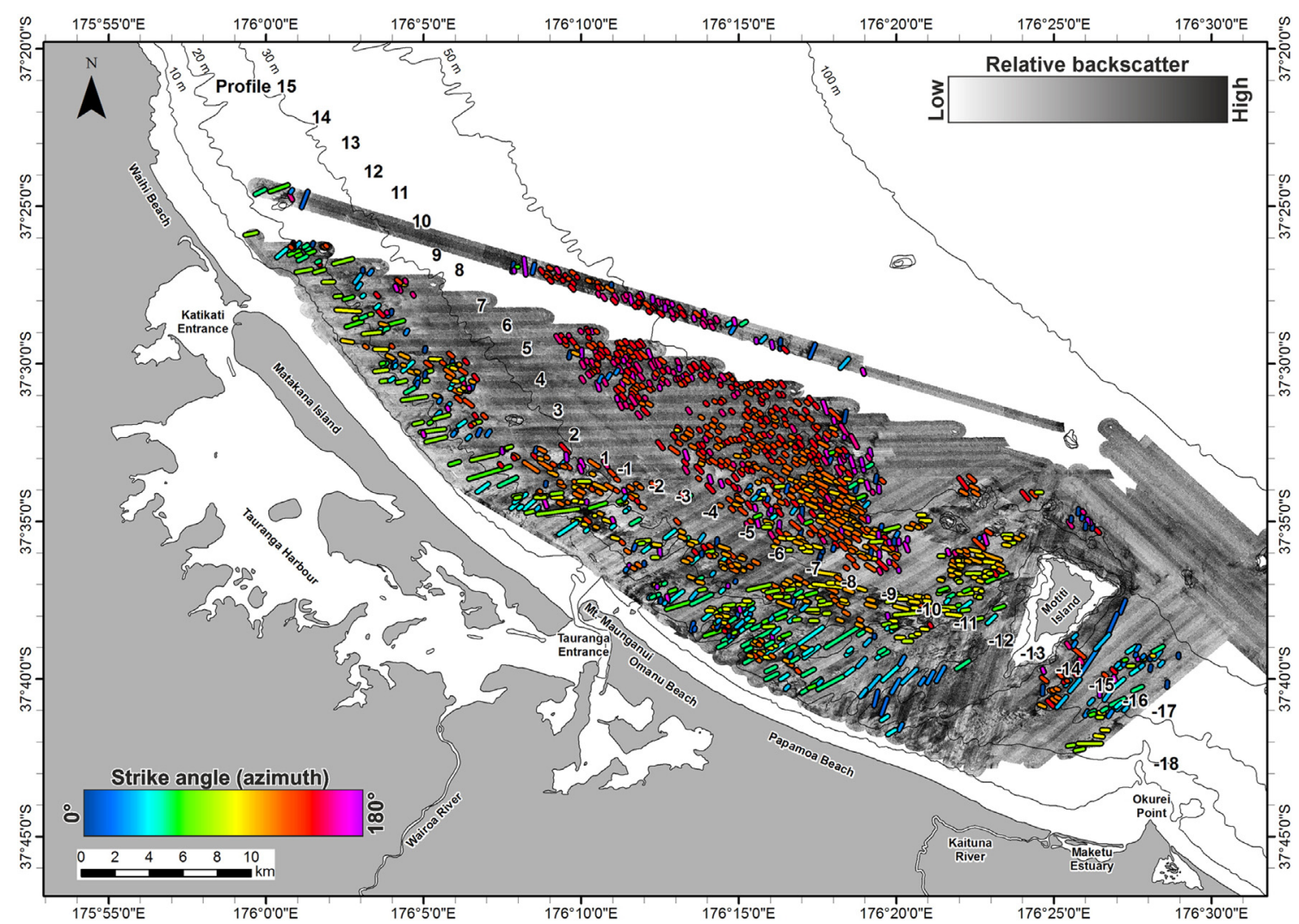

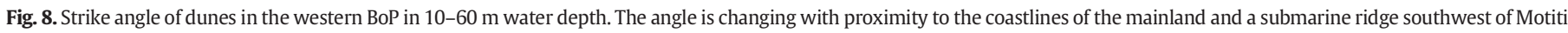
Island.

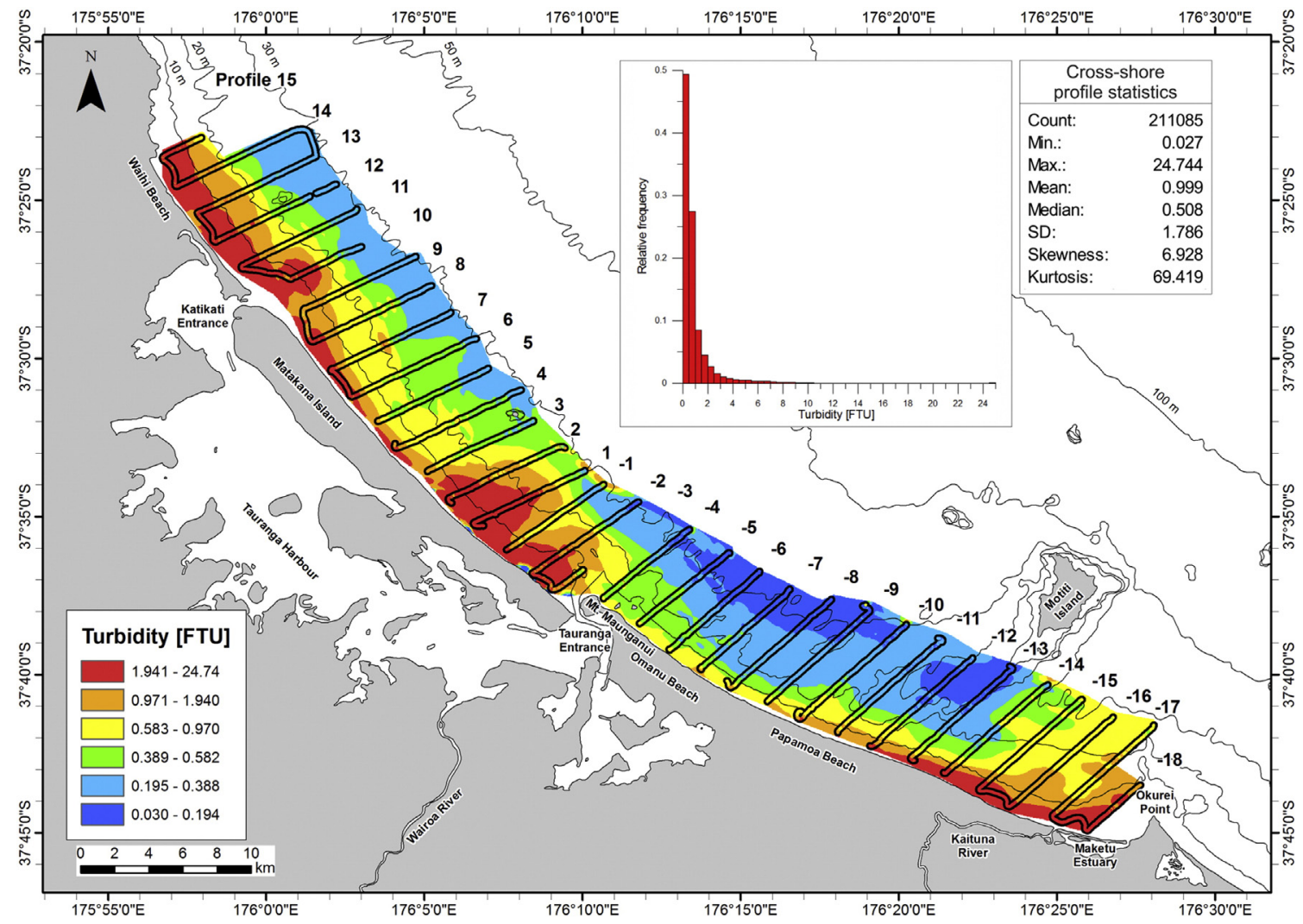

Fig. 9. Bottom water turbidity ( $0.5 \mathrm{~m}$ above the seafloor) in the study area on a quantile scale. 
The definition of lithofacies allows for a more detailed differentiation, but does not require the creation of entirely new facies boundaries as far as the spatial distribution is concerned (Fig. 10). With this as link to the acoustic facies, the number of samples necessary for reliable ground truthing can be kept small. Provided that environmental circumstances do not prevent the use of benthic profiler, e.g. through a rugged terrain, rock outcrops or coral reefs, this approach can be a valuable addition to seafloor mapping efforts.

\subsection{Lithofacies}

The lithofacies classification of seafloor sediments was achieved by combining the different datasets of photographic facies, grain size characteristics and mineral content in a joint model (see Table 1). This was done by matching the corresponding mineral facies type and grain size distribution groups. The final nomenclature is oriented on the existing photographic facies to take the appearance on a larger scale into account and simplify the comparison of these two schemes in the final lithofacies map.

In total, eight different lithofacies were defined:

- Lithofacies 1 , is a fine, mostly felsic sediment that encompasses all instances of the granulometric group A as well as the compositional type I. Through these two parameters it differs from all other sediments in the study area. The distribution is limited to a water depth of up to $20 \mathrm{~m}$ and matches up with the allochthonous Holocene deposits described by Bradshaw et al. (1994). This sediment, derived from fluvial infills of estuaries, has been deposited after the end of the sealevel rise $6.5 \mathrm{ka}$ ago. On lines that show a change from steeper to flatter slope profiles, the deeper limit of lithofacies 1 usually also coincides with a distinct bathymetric break at around $20 \mathrm{~m}$ depth. This is also the limit on generally flat profiles, such as those near the Maketu estuary). Only at Omanu Beach does it reach down to $30 \mathrm{~m}$. This area has a very steep bathymetric gradient between the beach and $20 \mathrm{~m}$ water depth, although the distance between the beach and the outer limit of the deposit is with ca. $5.5 \mathrm{~km}$ roughly the same as in the adjacent area on southern Papamoa Beach/Maketu. Presumably, this sediment has been mobilized in shallow water and transported in suspension over this distance until it could settle down.

- Lithofacies 2a belongs to the slightly more mafic compositional type II and is distinguished from other sediment of this type by the grain size distribution (group B, medium sand). Traces of volcanic glass are sometimes present, most likely in the finer grain sizes that make up the second mode of the distribution curve around $34 \mu \mathrm{m}$. This is probably an influence of lithofacies 1 as the finest and lightest particles can easily be entrained by waves and dispersed to a greater distance from the shore than the bulk of this deposit. If lithofacies 1 is identified with the allochthonous deposits, 2a (and indeed all other sediments belonging to this type of mineral composition) is equivalent to the early Holocene transgressionally reworked Pleistocene sands described by Bradshaw et al. (1994).

- Lithofacies $2 \mathrm{~b}$ is also part of the compositional type II and constitutes the granulometric group $C$. The sediment is a bit coarser than $2 \mathrm{a}$, and almost never contains volcanic glass. It appears that the unconnected locations where lithofacies $2 \mathrm{~b}$ is found are either too distant from lithofacies 1 to mix with finer younger sediments, or wave energy is too high to allow their deposition. The latter is the most likely case in the surroundings of sample 11 (see Fig. 1), an area in about $10 \mathrm{~m}$ water depth that would otherwise be typically occupied by lithofacies 1 .

- Lithofacies 3a is a coarse sand (group D) variety of mineral composition type II. The spatial distribution coincides with the deepest parts of the study area or bedforms that reflect erosional conditions like the center of the sorted bedforms at Papamoa Beach. It appears to be an older stage of the transgressional deposits underlying the previously described lithofacies.

- Lithofacies 3b differs from 3a by an even coarser grain size (group F). It occurs only in relatively small erosive areas within sorted bedforms and south of Motiti Island. As described above, much of the BoP

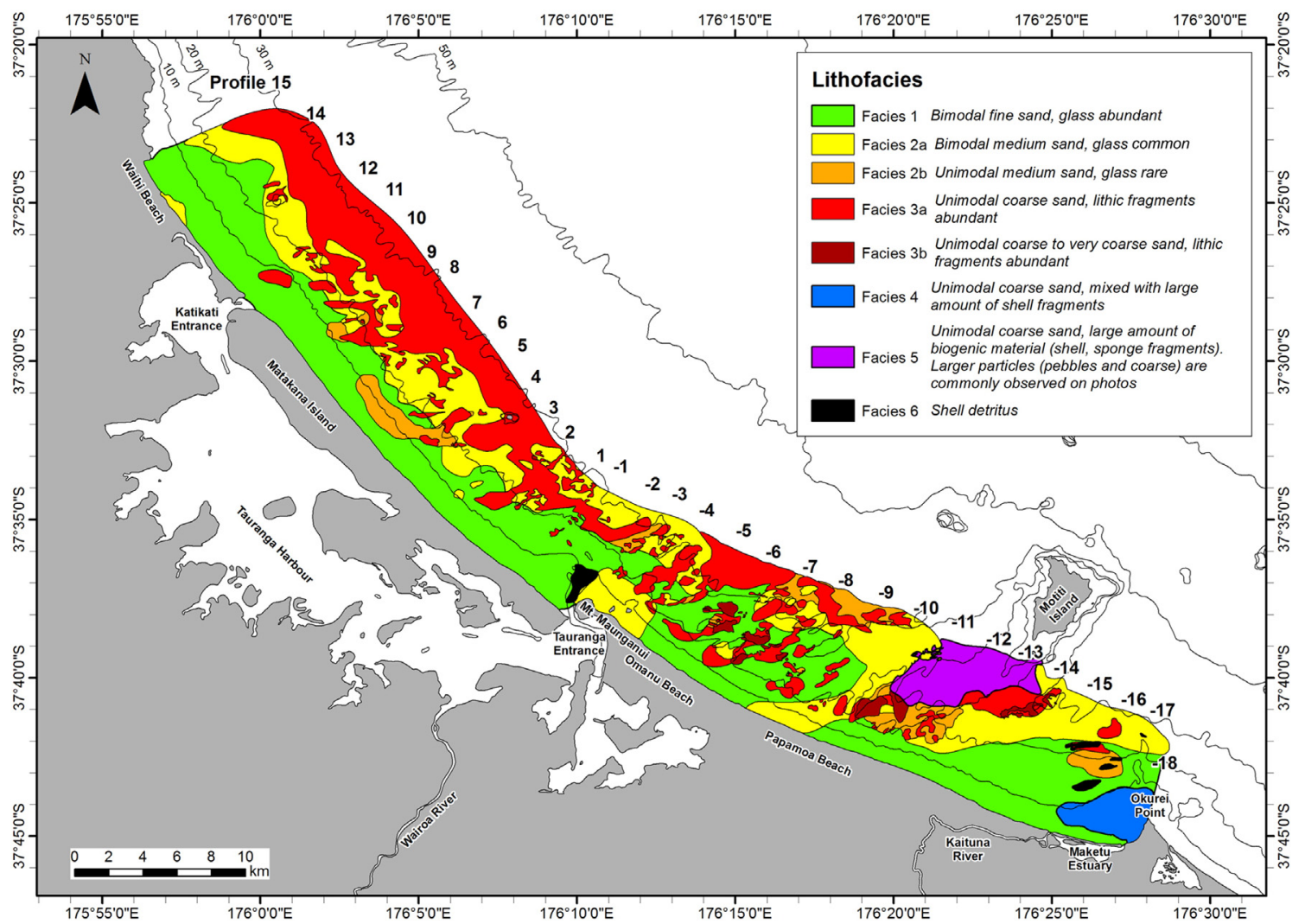

Fig. 10. Lithofacies inferred from granulometry, mineralogical composition and photographic appearance, spatial extent mapped by associated acoustic backscatter. 
Table 1

Relation of photographic, granulometric and mineralogical classifications to lithofacies.

\begin{tabular}{|c|c|c|c|c|c|c|c|}
\hline \multicolumn{2}{|r|}{ Photofacies (grain sizes are optical) } & \multicolumn{2}{|c|}{ Grain size distribution } & \multicolumn{2}{|c|}{ Mineral composition } & \multicolumn{2}{|c|}{ Lithofacies } \\
\hline 1 & Grayish black, medium sand & A & Bimodal fine sand & I & Ca. $2.5 \%$ mafic, volcanic glass & 1 & Widespread, late Holocene deposit \\
\hline 2 & Grayish black, medium to coarse sand & $\mathrm{B}$ & Bimodal medium sand & & & $2 \mathrm{a}$ & $\begin{array}{l}\text { Widespread, early Holocene deposit, some } \\
\text { mixing with facies } 1\end{array}$ \\
\hline & & $\mathrm{C}$ & Medium sand & II & Ca. $5 \%$ mafic, rock fragments, rare & $2 b$ & Patches, early Holocene deposit \\
\hline & & $\mathrm{D}$ & Coarse sand & & & $3 a$ & Widespread, early Holocene deposit \\
\hline 3 & Greenish black, coarse sand & $\mathrm{F}$ & Coarse to very coarse sand & & & $3 b$ & Patches, the oldest early Holocene deposit \\
\hline 4 & $\begin{array}{l}\text { Medium dark gray + light olive, coarse } \\
\text { to very coarse sand }\end{array}$ & $\mathrm{D}$ & Coarse sand & III & $\begin{array}{l}\text { Terrigenous fraction like II, ca. } \\
25 \% \text { biogenic carbonates }\end{array}$ & 4 & $\begin{array}{l}\text { Only at Okurei Point, transported shells } \\
\text { mixed with facies } 2 \text { b }\end{array}$ \\
\hline 5 & $\begin{array}{l}\text { Medium dark gray, very coarse sand; } \\
\text { pebbles, cobbles }\end{array}$ & $\mathrm{E}$ & $\begin{array}{l}\text { Coarse sand between pebbles, } \\
\text { cobbles }\end{array}$ & IV & $\begin{array}{l}\text { Terrigenous fraction similar to II, } \\
\text { ca. } 50 \% \text { biogenic carbonates }\end{array}$ & 5 & $\begin{array}{l}\text { Only south of Motiti Island, facies } 2 a / 3 a \\
\text { influenced by local sources }\end{array}$ \\
\hline 6 & Shell detritus & & & & & 6 & Shell detritus \\
\hline
\end{tabular}

sediments have been deposited during or after the Holocene transgression, which results a fining-upwards sequence. Therefore the coarse grain size of lithofacies 3a indicates that this likely belongs to the oldest deposit in the study area. Judging from the samples it is not entirely clear if this facies constitutes a separate layer under facies $3 a$ or is merely a local variation depending on a more energetic sorting process.

- Lithofacies 4 complies with nearly the same grain size group as lithofacies 3a (group D) as far as the bulk sediment is concerned. The largest components are shell fragments; all samples of compositional type III fall within this lithofacies. The terrigenous component is a medium sand of comparable composition as lithofacies $2 \mathrm{~b}$. This sediment is confined to a location at Okurei Point, which supports the assumption of a net littoral drift towards the southeast: the rocky headland is a natural barrier, where shell material fractured during transport accumulates along the coast. Waves reflected on the steep outcrop could prevent finer material from deposition.

- Lithofacies 5 consists mainly of coarse sand, but photographs of the surrounding seafloor commonly show larger particles up to the range of a decimeter (grain size group $\mathrm{E}$ ). The material includes all examples of compositional type IV. The high biogenic component includes shells in all stages of disaggregation from complete halves to fragments, as well as parts of sponges. The terrigenous component is similar to lithofacies 3a, but it includes pebble-sized components that are significantly larger than anything found in 3a or 3b. It can be assumed that this sediment is mixed with material originating from the nearby Motiti Island.

- Lithofacies 6 is a shell detritus deposit, but the underlying sediment could not be determined.

\subsection{Bedforms and sediment dynamics}

The littoral drift of sediment in the study area has been repeatedly determined at multiple locations in past studies (Healy, 1977; Harray and Healy, 1978; Hicks et al., 1999; Healy and De Lange, 2014) as essentially bidirectional but with the net component directed towards the southeast. According to the model for the neighboring inner Coromandel shelf by Bradshaw et al. (1994), sediment transport in fair weather conditions is limited to on- and offshore transport by waves and rip currents, with a SE flux component up to $10 \mathrm{~m}$ water depth (Badesab et al., 2012). The datasets used in this study contain little additional information about the situation in shallow water as the sidescan sonar map only starts at 10-15 m. However, the observed bedforms below that depth agree with Bradshaw et al. (1994): all indications point to a northwesterly-directed transport between $10-15 \mathrm{~m}$ and $30 \mathrm{~m}$ water depth between Papamoa and Waihi Beach.

\subsubsection{Subaquatic dunes}

The first piece of evidence for this interpretation comes from the orientation of bedforms. A closer examination of strike angles shows that dunes can be placed into one of two groups: the first includes dunes striking - in first approximation - perpendicular to the coastline ("shore-normal" in Fig. 11). Their strike angle is on average $51^{\circ}$ to true north, although this is mostly due to a large number small-scale structures; the larger dunes in close proximity to the shore are closer to $75^{\circ}$ azimuth $-\mathrm{ca} .60^{\circ}$ to the shoreline. Those in the second group strike along the coastline ("shore-parallel", $125^{\circ}$ ) and are less varied in their orientation.

Dunes belonging to the "shore-normal" group are concentrated in the depth range from 10 to $30 \mathrm{~m}$, but no such restriction could be found for "shore-parallel" dunes. As our survey was limited to a maximum depth of up to $35 \mathrm{~m}$, only the bedforms within this range have been statistically examined. A total number of 285 structures with an average width of $428 \mathrm{~m}$ (parallel to the crest) and wavelength between 0.5 and $1.3 \mathrm{~km}$ have been classified as "shore-normal". Examples of "shore-parallel" dunes appear in almost equal numbers (273 dunes) but are much smaller with an average width of $256 \mathrm{~m}$ and a wavelength of $0.1-0.3 \mathrm{~km}$.

Backscatter usually decreases at first gradually towards the northwestern side of "shore-normal" and on the southwestern side of "shore-parallel" dunes, then decreases again rapidly to an area of minimal backscatter, then increases again abruptly to another maximum. In some cases, photographs and multibeam data are available on or reasonably close to these areas of high backscatter. It appears that the high backscatter is caused by the accumulation of large shells and shell fragments close to the dune trough. The material gets sorted out on the stoss slope of the dune and disappears completely before the change to minimum backscatter; this point marks the dune crest (Fig. 12).

Shore-oblique nearshore bedforms of similar dimensions have been observed on storm-dominated shelves of the northwestern (Duane et al., 1972; Swift et al., 1972) and southwestern Atlantic (Figueiredo et al., 1982; Parker et al., 1982). However, the Atlantic sand ridges have a much smaller angle to the shore than the bedforms in the BoP, between 1 and 50 (McKinney et al., 1974; Swift and Field, 1981) and on average ca. $30^{\circ}$ (Figueiredo et al., 1982; Parker et al., 1982; Goff et al., 1999). The responsible longshore current responds faster to wind stress and is consequently stronger in shallow water, and so sediment is transported faster here than in greater depth (Swift and Field, 1981; Goff et al., 2015). These structures are maintained by the offshore deflection of storm-driven longshore currents at their crests (Trowbridge, 1995; Calvete et al., 2001). In all cases, the angle opens in the upcurrent direction: to the north on the North American and to the south on the South American east coast. In the case of the BoP, the obliquity of dunes points to a SE-NW directed current.

The unusually large opening angle of the BoP dunes is a striking difference to other storm-dominated shelves. A key difference in the wave and current climate of the North American and the BoP shelf appears to be wind direction during storms. The BoP experiences mostly onshore directed easterly and northeasterly winds of passing tropic cyclones. According to Bradshaw et al. (1991), these first lead to a downwelling 


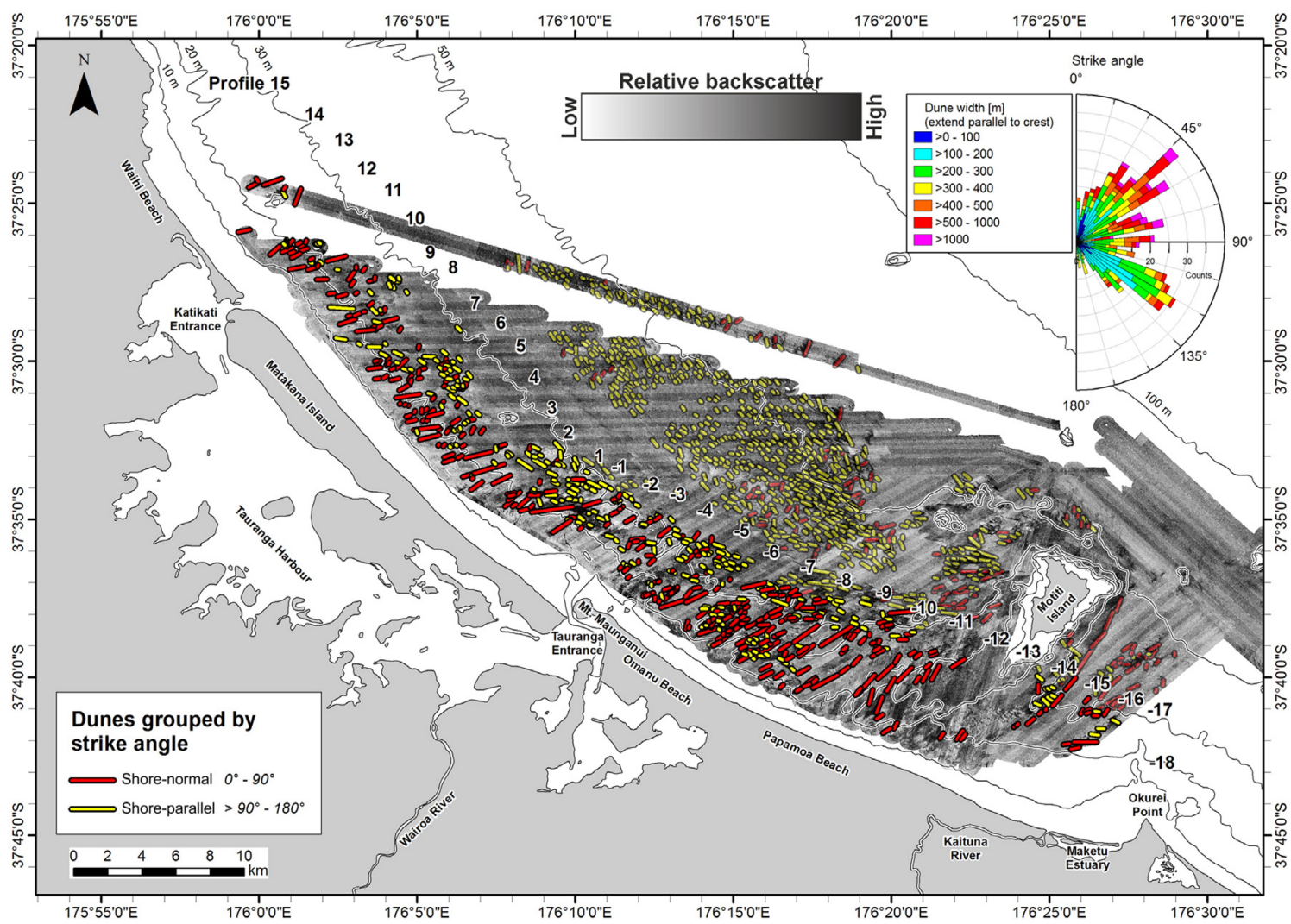

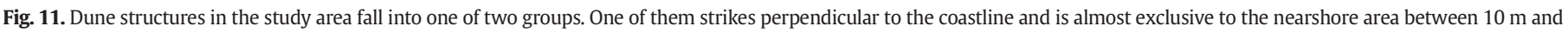
$30 \mathrm{~m}$. The other strikes parallel to the coastline and is found in all water depths. Only dunes in the nearshore area (strong colors) are included in the analysis.

current which is subsequently deflected to the northwest by balancing the cross-shore pressure gradient and Coriolis forces. Sediment entrained by storm waves is transported by this current. Depending on the angle of the incoming waves to the shoreline, an additional and opposite NW-SE directed current may sometimes develop on the upper shoreface (Niedoroda et al., 1985); however, as most wave fronts hit the coast at an almost right angle (see Fig. 1) this will seldom be the case. The North American east coast is also frequented by northeasterly storms, but due to the NE-SW orientation of the shoreline those have a stronger longshore component. Subsequent currents follow this direction (Dragos and Aubrey, 1990; Trowbridge, 1995). Goff et al. (2015) predicts that flow-traverse bedforms will over time develop a more acute angle to the shore due to the in cross-shore direction differing flow velocity. As the longshore current is directly forced by the wind stress, the cross-shore velocity gradient is relatively large. In the BoP, the downwelling current loses energy with distance to the shore, but at the same time the remaining energy flux is more and more shifted in longshore direction. This could result in a less varied velocity gradient from shallow to deep water. Unfortunately there are currently no current meter datasets available to test this hypothesis.

Regarding the bedforms in deeper parts of the BoP, the available data provide no indication whether these have been formed by recent or past

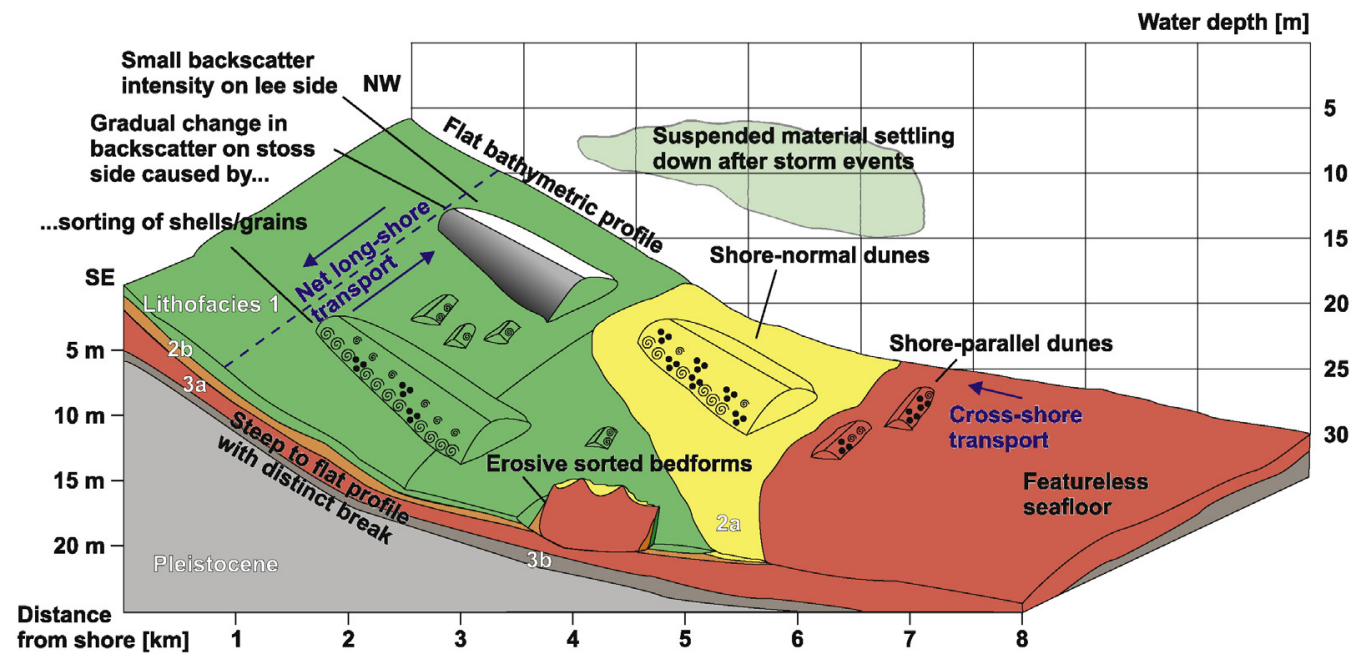

Fig. 12. Schematic view of the coastal environment of the western BoP with sediment structures and stratigraphic arrangement of lithofacies. The thickness of the individual layers is estimated from seismic units from Bradshaw and Nelson (2004). 
processes. If these features are still dynamic, the transition of shoreparallel dunes to a featureless section between 30 and $40 \mathrm{~m}$ and the recurrence of dunes in shallower water could be explained by the energy distribution of the responsible waves. It is possible that approaching swell transfers its highest shear stress to the seafloor at $30-40 \mathrm{~m}$ depth before it loses energy due to friction in shallow water. In that case, the featureless section could represent the plane bed stage of the upper flow regime, which means that sediment would be transported towards the shore from as deep as $60 \mathrm{~m}$.

\subsubsection{Sorted bedforms and coarse sand ribbons}

A second indicator for transport direction is the uniform shape and orientation of sorted bedforms, which are elongated in cross-shore direction with a sharp boundary towards southeast. This is the case both for small, poorly developed bedforms offshore Matakana Island and for the very large, distinctive features at Omanu Beach. Similarly developed bedforms, although with dimensions comparable to those along Matakana Island, have been monitored by Spiers and Healy (2007) close to Mt. Maunganui. Spiers and Healy (2007) related these structures to zones of wave convergence created by the offshore dumping grounds in that area. If a similar process is involved in the formation of the well developed Omanu bedforms, Motiti Island or one of the several local elevations in the immediate neighborhood of these sorted bedforms could possibly lend themselves to wave convergence. In any case, considering the water depth and related low wave energy (Badesab et al., 2012), the waves in question have to be storm induced to affect the seafloor; DeFalco et al. (2015) provide another example of sorted bedforms formed during periodic storm events.

As studies like Coco et al. (2007) have shown, it is possible for sorted bedforms to be created by unmixing of a poorly sorted sediment; however, it is unlikely that this process is responsible here for two reasons: 1) there is no source sediment in the system with a wide enough range of grain sizes and 2) the coarse sediment inside the sorted bedforms is identical to other examples of the underlying lithofacies $3 \mathrm{a}$ and $3 \mathrm{~b}$. With this in mind, it appears that these features were originally formed either by erosion of lithofacies 1 to the point that the underlying strata were exhumed, or alternatively lithofacies 1 was never deposited in these locations in the first place. The low turbidity in the surroundings of the sorted bedforms again indicates that erosion, but also deposition of suspended material is limited during fair weather conditions. Observations of bedforms created in an erosive environment on a coarse bed overlain by finer sediment were also made by other studies, for example on bedforms in Shinnecock Inlet (New York) and Grays Harbor (Washington) by Ferrini and Flood (2005) (there classified as type II rippled scour depressions). Either process can be linked to the mechanism of increased turbulence proposed by Murray and Thieler (2004) and others, that is keeping these bedforms stable.

The orientation of coarse sand ribbons has in the past been interpreted as parallel to the current responsible for their creation (Goff et al., 1999; Feldens et al., 2015). As such, they show coast parallel sediment transport, except south of Motiti Island (along profile 14). It appears that in this area sediment is transported cross-shore below $10 \mathrm{~m}$ water depth.

\subsubsection{Turbidity and lithofacies distribution}

With consideration of turbidity, it appears that the environment along Matakana is overall more dynamic than the Omanu/Papamoa region. The measurements indicate a link between turbidity and bathymetric gradient between 0 and $20 \mathrm{~m}$ water depth. More sediment is in suspension (and in greater depth) in the northern region than along the relatively steep southern coastline of the study area. This is a matter of local entrainment, but also availability of sediment from external sources. Only the southeastern end of the study area, in proximity to the Kaituna River, shows a level of turbidity that is comparable to (or even greater than) the Matakana coast. Sediment in this location appears to be dispersed either offshore or is bypassing Okurei Point.
Some minor input may be delivered directly from Motiti, but considering the extent of the different lithofacies in this area and the lack of sediment structures, the submarine ridge appears to act as a barrier for sediment transport in any direction. The low turbidity, but great extent of lithofacies 1 and 2a offshore Omanu Beach (from 5 to $30 \mathrm{~m}$ depth, almost $10 \mathrm{~m}$ deeper than anywhere else) could be explained by a periodic entrainment of a large volume of sediment close to the beach, which is transported in suspension offshore by a relatively strong current as described by Niedoroda et al. (1984). A plausible scenario is a storm driven transport initiated by an initially onshore directed current parallel to the Motiti ridge, that is in turn pushing a downwelling current offshore and away from Omanu Beach. After the storm has ended, upwelling can take place, but this current is relatively weak and without wave action unable to re-entrain (Badesab et al., 2012) the deposited sediment (Niedoroda et al., 1984).

\subsubsection{Conceptual sediment transport}

By combining these observations about the nature and extent of sediment facies, of bedforms, of the distribution of suspended material and the comparison to the published literature, a general sediment transport model can take the net transport directions as well as the location of hypothesized centers of erosion/non-deposition into account (Fig. 13). Using the approximate thickness of seismic units from Bradshaw and Nelson (2004) (sheet-like late Holocene fine sands on top of ca. $5 \mathrm{~m}$ early Holocene coarse sand) as a rough guideline, a schematic stratigraphy of the upper 5-10 m of seafloor of the western BoP coastal system could be developed (Fig. 12). Of course, for a reliable model of the geologic structure sediment cores would be a necessity. These would also give valuable insight into the internal structure of the large sorted bedforms; at this point it is unclear if these features are indeed purely erosive or if there are periods of fine sand deposition as observed in other places (Murray and Thieler, 2004; Trembanis and Hume, 2011).

\section{Conclusions}

The sedimentology of the western Bay of Plenty has been mapped by a combined optical, acoustic and sampling based approach, which has provided a higher level of resolution than conventional lithofacies mapping studies. The results fit well with the previously established environment of the Bay of Plenty and inner Coromandel shelf. Eight distinct lithofacies categories were defined and mapped. The nearshore area is dominated by fine sand that contains plagioclase, quartz, few mafic minerals and an amorphous phase (presumably volcanic glass). At greater distance from the shore, gradually coarser sediments have been deposited that differ mineralogically from the fine sand by higher amounts of mafics, absence of volcanic glass, and the presence of lithic fragments. These sediment can be linked to similar deposits on the inner Coromandel shelf and are interpreted as early to late Holocene sand reworked from Pleistocene deposits overlain by late Holocene allochthonous sediments.

Net sediment transport is directed from northwest to southeast close to shore, as had been established in this and adjacent regions by earlier studies (e.g. Davies-Colley and Healy, 1978b; Bradshaw et al., 1994; Hicks et al., 1999; Bear et al., 2009; Badesab et al., 2012). In depths greater than 10-15 m, only indications for a northwesterly directed transport were found. These opposing directions are likely due to the transport of wave-entrained sediment by a southeastern littoral drift prevalent under normal weather conditions vs. the usual direction of storm waves approaching the shore from northeast inducing the downwelling of water masses which are deflected to the northwest as a geostrophic current (Harray and Healy, 1978; Bradshaw et al., 1991, 1994). Both transport systems are connected by the cross-shore transport of sediments, only shoreward directed transport appears to lead to the creation of indicative bedforms such as coast-parallel striking dunes. Cross-shore transport is the only process taking place below a 


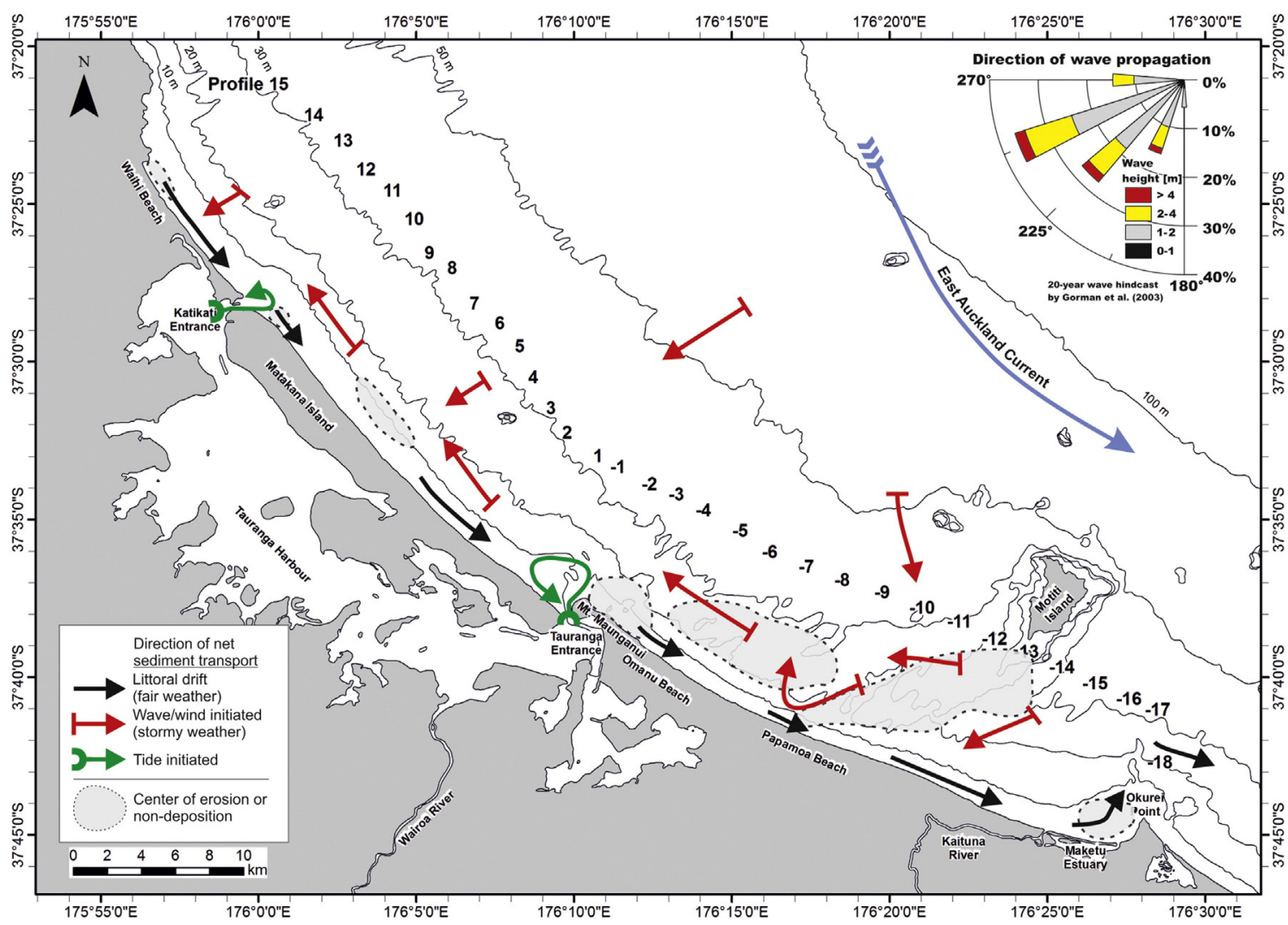

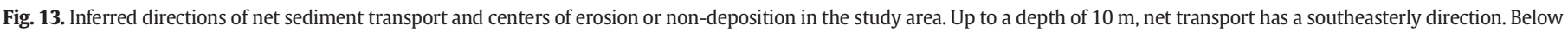
that depth, net transport is directed towards the northwest. No longshore sediment transport is taking place below $30 \mathrm{~m}$.

depth of 30-35 m, indicators for this process have been observed in a water depth of up to $60 \mathrm{~m}$. The northern half of the study area along the barrier island of Matakana was found to be more dynamic than the region southeast of Mt. Maunganui. There is little to no deposition of sediment offshore of Omanu Beach which has no sources of riverine input and is located between two natural barriers for sediments: Tauranga Entrance to the northwest and the submarine Motiti ridge to the southeast. Sorted bedforms of various dimensions have been found and their origin interpreted as erosional rather than due to the unmixing of grains.

Overall, the method developed in this study for an assessment of sediment classification, distribution and dispersal by combining datasets of varying dimensions and resolution led to convincing results. The high density of data along benthic profiles enables a detailed delineation of adjacent facies and the association with area covering acoustic backscatter provides the necessary information for two-dimensional mapping. Used as a guidance for targeting specific sampling locations, this approach leads to a highly detailed insight into the local sediment facies. In an environment where no major obstacles (rock outcrops, coral reefs, etc.) prevent the use of a benthic sled, the usefulness of close-up seafloor photography is apparent and has potential for future improvements. Considering the time and effort a manual photographic sediment classification requires, an automatic scheme would need to be developed before this method could find widespread application.

\section{Acknowledgments}

We thank Dirk Immenga, Chris Morcom, Chris Eager and Brice Blossier for their guidance and assistance in the sampling campaign and Christian Hilgenfeldt and Benjamin Baasch for their participation in the 2012 NERIDIS survey. That survey took place using the Western Workboats vessel MACY GRAY with great support by Henry Wolfenden and Sean Kelly. Annette Rodgers, Janine Ryburn, Ganqing $\mathrm{Xu}$ and
Renat Radosinsky of the University of Waikato technical staff provided valuable help in diverse sedimentological and mineralogical laboratory measurements. Seaworks Ltd. generously provided raw sidescan sonar data. Development of the NERIDIS camera system was supported by Leif Christensen from the German Research Center for Artificial Intelligence (DFKI), and Prof. Oliver Zielinski and Dr. Jan Schulz from the ICBM, University of Oldenburg. At the University of Bremen, we thank Michael Wendschuh for advice in the interpretation of XRD data and Konstantin Reeck for the processing of diverse datasets. This work includes LINZ's data which are licensed by Land Information New Zealand (LINZ) for re-use under the Creative Commons Attribution 3.0 New Zealand licence. The deployment of NERIDIS was financed by the RENA Long Term Environmental Recovery Monitoring Program. This study is a project of the collaborative graduate school INTERCOAST of the universities of Bremen and Waikato, with financing provided by the German Research Foundation (Deutsche Forschungsgesellschaft, DFG). Finally, we thank two anonymous reviewers for their insightful comments.

\section{References}

Baasch, B., Müller, H., Oberle, F.K.J., von Dobeneck, T., 2015. Inversion of marine multifrequency electromagnetic profiling data: a new approach to resolve surficial sediment stratification. Geophys. J. Int. 200, 439-451.

Badesab, F., von Dobeneck, T., Bryan, K.R., Müller, H., Briggs, R.M., Frederichs, T., Kwoll, E., 2012. Formation of magnetite-enriched zones in and offshore of a mesotidal estuarine lagoon: an environmental magnetic study of Tauranga Harbour and Bay of Plenty, New Zealand. Geochem. Geophys. Geosyst. 13, Q06012. http://dx.doi.org/10.1029/ 2012GC004125.

Barnhardt, W.A., Kelley, J.T., Dickson, S.M., Belknapt, D.F., 1998. Mapping the Gulf of Maine with side-scan sonar: a new bottom-type classification for complex seafloors. J. Coast. Res. 14 (2), 646-659.

Battershill, C., Schiel, D.R., Ross, P.M., Fairweather, R., Culliford, D., Marsh, R., Taiapa, C., Bennett, P., 2013. Rena Environmental Recovery Monitoring Programme: executive summary. Te Mauri Moana. Environmental Research Institute, University of Waikato, Tauranga, New Zealand (37 pp.). 
Bear, A.L., Healy, T.R., Immenga, D.K., 2009. Coastal erosion and sedimentation processes at Waihi Beach, New Zealand. J. Coast. Res. Spec. Issue 56, 1721-1725.

Blott, S.J., Pye, K., 2001. GRADISTAT: a grain size distribution and statistics package for the analysis of unconsolidated sediments. Earth Surf. Process. Landf. 26, 1237-1248.

Bradshaw, B.E., Healy, T.R., Dell, P.M., Bolstad, W.M., 1991. Inner shelf dynamics on a storm-dominated coast, East Coromandel, New Zealand. J.Coast. Res. 7 (1), 11-30.

Bradshaw, B.E., Healy, T.R., Campbell, S.N., Dell, P.M., De Lange, W.P., 1994. Holocene sediment lithofacies and dispersal systems on a storm-dominated, back-arc shelf margin: the east Coromandel coast, New Zealand. Marine Geol. 119, 75-98.

Bradshaw, B.E., Nelson, C.S., 2004. Anatomy and origin of autochthonous late Pleistocene forced regression deposits, east Coromandel inner shelf, New Zealand: implications for the development and definition of the regressive systems tract. N. Z. J. Geol. Geophys. 47, 81â€“99.

Brodie, J.W., 1960. Coastal surface currents around New Zealand. N. Z. J. Geol. Geophys. 3 (2), 235-252. http://dx.doi.org/10.1080/00288306.1960.10423596.

Briggs, R.M., Houghton, B.F., McWilliams, M., Wilson, C.J.N., 2005. ${ }^{40} \mathrm{Ar} /{ }^{39} \mathrm{Ar}$ ages of silicic volcanic rocks in the Tauranga-Kaimai area, New Zealand: dating the transition between volcanism in the Coromandel Arc and the Taupo Volcanic Zone. N. Z. J. Geol. Geophys. 48, 459-469.

Burton, J.H., Healy, T.R., 1985. Tidal hydraulics and stability of the Maketu Inlet, Bay of Plenty. 1985 Australasian Conference on Coastal and Ocean Engineering 1985. Barton, A.C.T.: Institution of Engineers, Australia, pp. 697-702.

Cacchione, D.A., Drake, D.E., 1984. Rippled scour depressions on the inner continental shelf off central California. J. Sediment. Petrol. 54 (4), 1280-1291.

Calvete, D., Walgreen, M., de Swart, H.E., Falqués, A., 2001. A model for sand ridges on the shelf: effect of tidal and steady currents. J. Geophys. Res. 106 (C5), 9311-9325.

Carter, L., Heath, R.A., 1975. Role of mean circulation, tides and waves in the transport of bottom sediment on the New Zealand continental shelf. N. Z. J. Mar. Freshw. Res. 9, 423-448.

Coco, G., Murray, A.B., Green, M.O., 2007. Sorted bed forms as self-organized patterns: 1. Model development. J. Geophys. Res. 112, F03015. http://dx.doi.org/10.1029/ 2006JF000665.

Cole, J.W., 1979. Structure, petrology, and genesis of Cenozoic volcanism, Taupo Volcanic Zone, New Zealand-a review. N. Z. J. Geol. Geophys. 22 (6), 631-657.

Davis Jr., R.A., Healy, T.R., 1993. Holocene coastal depositional sequences on a tectonically active setting: southeastern Tauranga Harbour, New Zealand. Sediment. Geol. 84 57-69.

Davies-Colley, R.J., Healy, T.R., 1978a. Sediment and hydrodynamics of the Tauranga entrance to Tauranga harbour. N. Z. J. Mar. Freshw. Res. 12 (3), 225-236.

Davies-Colley, R.J., Healy, T.R., 1978b. Sediment transport near the Tauranga entrance to Tauranga. N. Z. J. Mar. Freshw. Res. 12 (5), 237-243.

De Lange, W.P., 1988. Wave Climate and Sediment Transport Within Tauranga Harbour, in the Vicinity of the Pilot Bay. University of Waikato, Hamilton, New Zealand (Ph.D. thesis, 189 pp.).

DeFalco, G., Budillon, F., Conforti, A., Di Bitetto, M., Di Martino, G., Innangi, S., Simeone, S Tonielli, R., 2015. Sorted bedforms over transgressive deposits along the continental shelf of western Sardinia (Mediterranean Sea). Mar. Geol. 359, 75-88.

Dragos, P., Aubrey, D.G., 1990. Atlantic shelf sand ridge study: physical oceanography and sediment dynamics data report. Woods Hole Oceanographic Institute Technical Report, WHOI-90-11, CRC-90-1 1990. Woods Hole, Massachusetts.

Duane, D.B., Field, M.E., Miesberger, E.P., Swift, D.J.P., Williams, S.J., 1972. Linear shoals on the Atlantic continental shelf, Florida to Long Island. In: Swift, D.J. Duane, D.B Pilkey, O.H. (Eds.), Shelf Sediment Transport: Process and Pattern. Van Nostrand Reinhold, New York, pp. 447-498 (1972).

Erdey, M.D., Cochrane, G.R., 2015. Seafloor-character map of the offshore of Point Reyes map area (sheet 5). In: Watt, J.T., Cochran, S.A. (Eds.), California State Waters Map Series - Offshore of Point Reyes, California. U.S. Geological Survey Open-File Report 2015-1114 pamphlet 39 pp., 10 sheets, scale 1:24,000, http://dx.doi.org/10.3133/ ofr20151114.

Ewart, A., 1965. Review of mineralogy and chemistry of the acidic volcanic rocks of Taupo volcanic zone, New Zealand. Bull. Volcanol. 29 (1), 147-171.

Feldens, P., Diesning, M., Schwarzer, K., Heinrich, C., Schlenz, B., 2015. Occurrence of flow parallel and flow transverse bedforms in Fehmarn Belt (SW Baltic Sea) related to the local palaeomorphology. Geomorphology 231, 53-62.

Fernlund, J.M.R., 2005. Image analysis method for determining 3-D shape of coarse aggregate. Cem. Concr. Res. 35, 1629-1637.

Ferrini, V.L., Flood, R.D., 2005. A comparison of Rippled Scour Depressions identified with multibeam sonar: evidence of sediment transport in inner shelf environments. Cont. Shelf Res. 25, 1979-1995.

Figueiredo, A.G., Sanders, J.E., Swift, D.J.P., 1982. Storm-graded layers on inner continental shelves: examples from southern Brazil and the Atlantic Coast of the central United States. Sediment. Geol. 31, 171-190.

Foster, G.A., Healy, T.R., De Lange, W.P., 1994. Sediment budget and equilibrium for a moderate swell regime, ebb-tidal adjacent beach, Mt. Maunganui, New Zealand. J. Coast. Res. 10 (3), 564-575.

Foster, G.A., Healy, T.R., De Lange, W.P., 1996. Presaging beach renourishment from a nearshore dredge dump mound, Mt. Maunganui Beach, New Zealand. J. Coast. Res. $12(2), 395-405$

Frihy, O.E., 1994. Discrimination of accreted and eroded coasts using heavy mineral compositions of the Nile Delta beach sands, Egypt. Sedimentology 41, 905-912.

Gao, S., Collins, M.B., 2014. Holocene sedimentary systems on continental shelves. Mar. Geol. 352, 268-294.

Gibb, J.G., 1994. Initial assessment of areas sensitive to coastal hazards for selected parts of the Bay of Plenty coast. Consultancy Report CR94/I 7 for Bay of Plenty Regional Council, Tauranga, New Zealand (36 pp. + app).
Goff, J.A., Swift, D.J.P., Duncan, C.S., Mayer, L.A., Hughes-Clark, J., 1999. High-resolution swath sonar investigation of sand ridge, dune and ribbon morphology in the offshore environment of the New Jersey margin. Mar. Geol. 161, 307-337.

Goff, J.A., Flood, R.D., Austin Jr., J.A., Schwab, W., Christensen, B., Browne, C.M., Denny, J.F., Baldwin, W.E. 2015. The impact of Hurricane Sandy on the shoreface and inner shelf of Fire Island, NewYork: large bedform migration but limited erosion. Cont. Shelf Res. 98, 13-25.

Gorman, R.M., Bryan, K.R., Laing, A.K., 2003. Wave hindcast for the New Zealand region: nearshore validation and coastal wave climate. N. Z. J. Mar. Freshw. Res. 37 (3), 567-588. http://dx.doi.org/10.1080/00288330.2003.9517190.

Green, M.O., Vincent, C.E., Trembanis, A.C., 2004. Suspension of coarse and fine sand on a wave-dominated shoreface, with implications for the development of rippled scour depressions. Cont. Shelf Res. 24, 317-335.

Hanquiez, V., Mulder, T., Lecroart, P., Gonthier, E., M., Marchès Voisset, 2007. High resolution seafloor images in the Gulf of Cadiz, Iberian margin. Mar. Geol. 246, 43-59.

Harray, K.G., Healy, T.R., 1978. Beach erosion at Waihi Beach, Bay of Plenty, New Zealand. N. Z. J. Mar. Freshw. Res. 12 (2), 99-107.

Healy, T.R., 1977. Progradation at the entrance, Tauranga Harbour, Bay of Plenty. N. Z Geogr. 33 (2), 90-92

Healy, T.R., De Lange, W.P., 2014. Reliability of geomorphic indicators of littoral drift: examples from the Bay of Plenty, New Zealand. J. Coast. Res. 30 (2), 301-318.

Healy, T.R., Kirk, R.M., 1982. Coasts. In: Soons, J.M., Selby, M.J. (Eds.), Landforms of New Zealand. Longman Paul, Auckland, pp. 81-104

Healy, T.R., Harray, K.G., Richmond, B., 1977. The Bay of Plenty Coastal Erosion Survey Occasional Report No. 3. Department of Earth Sciences, The University of Waikato, Hamilton (64 pp.)

Healy, T.R., Harms, C., De Lange, W.P., 1991. Dredge spoil and inner shelf investigations of Tauranga Harbour, Bay of Plenty, New Zealand. Coastal Sediments '91. ASCE Seattle, Washongton, pp. 2037-2051.

Healy, T.R., Cole, R., De Lange, W.P., 1996. Geomorphology and ecology of New Zealand shallow estuaries and shorelines. In: Nordstrom, K.F., Roman, C.T. (Eds.), Estuarine Shores, Evolution, Environments and Human Alterations. Wiley \& Sons, London, pp. 115-154 (1996).

Henry, M.A.C., 1991. The Volcanic Geology of Motiti Island Unpublished M.Sc. thesis lodged in the Library University of Waikato, Hamilton, New Zealand.

Heward, A.P., 1981. A review of wave-dominated clastic shoreline deposits. Earth-Sci. Rev. $17,223-276$.

Hicks, D.M., Hume, T.M., 1996. Morphology and size of ebb tidal deltas at natural inlets on open-sea and pocket-bay coasts, North Island, New Zealand. J. Coast. Res. 12 (1), 47-63.

Hicks, D.M., Hume, T.M., 1997. Determining sand volumes and bathymetric change on an ebb-tidal delta. J. Coast. Res. 13 (2), 407-416.

Hicks, D.M., Hume, T.M., Swales, A., Green, M.O., 1999. Magnitudes, spatial extent, time scales and causes of shoreline change adjacent to an ebb tidal delta, Katikati Inlet, New Zealand. J. Coast. Res. 15 (1), 220-240.

NERMN beach profile monitoring 2011. In: Iremonger, S. (Ed.), Bay of Plenty Regional Council Environmental Publication 2011/14.

Kostylev, V.E., Todd, B.J., Fader, G.B.J., Courtney, R.C., Cameron, G.D.M., Pickrill, R.A., 2001. Benthic habitat mapping on the Scotian Shelf based on multibeam bathymetry, surficial geology and sea floor photographs. Mar. Ecol. Prog. Ser. 219, $121-137$

Krüger, J.C., Healy, T.R., 2006. Mapping the morphology of a dredged ebb tidal delta Tauranga Harbour, New Zealand. J. Coast. Res. 22 (3), 720-727.

Leonard, B.S., J.G., Begg, Wilson, C.J.N., 2010. Geology of the Rotorua Area - Institute of Geological and Nuclear Sciences 1:250000 Geological Map 51 sheet +102 pp. GNS Science, Lower Hutt, New Zealand. (compilers).

Li, G., Yan, W., Zhong, L., Xia, Z., Wang, S., 2015. Provenance of heavy mineral deposits on the northwestern shelf of the South China Sea, evidence from single-mineral chemistry. Mar. Geol. 363, 112-124.

Lobo, F.J., Hernández-Molina, F.J., Somoza, L., Rodero, A., Maldonado, A., Barnolas, A., 2000. Patterns of bottom current flow deduced from dune asymmetries over the Gulf of Cadiz shelf (southwest Spain). Mar. Geol. 164, 91-117.

Macky, G.H., Latimer, G.J., Smith, K., 1995. Wave climate of the western Bay of Plenty, New Zealand, 1991-93. N. Z. J. Mar. Freshw. Res. 29 (3), 311-327.

Mayer, L.A., 2006. Frontiers in seafloor mapping and visualization. Mar. Geophys. Res. 27, 7-17. http://dx.doi.org/10.1007/s11001-005-0267-X.

McKinney, T.F., Stubblefield, W.F., Swift, D.J.P., 1974. Largescale current lineations on the central New Jersey shelf: investigation by side-scan sonar. Mar. Geol. 17, 79-102.

Michels, K.H., Healy, T.R., 1999. Evaluation of an inner shelf site off Tauranga Harbour New Zealand, for disposal of muddy-sandy dredged sediments. J. Coast. Res. 13 (3) 830-838.

Milkov, A., Vogt, P., Cherkashev, A., Ginsburg, G., Chernova, N., Andriashev, A., 1999. Seafloor terrains of Haskon Mosby Mud Volcano as surveyed by deep-tow video and stil photography. Geo-Mar. Lett. 19, 38-47.

Müller, H., von Dobeneck, T., Hilgenfeldt, C., SanFilipo, B., Rey, D., Rubio, B., 2012. Mapping the magnetic susceptibility and electric conductivity of marine surficial sediments by benthic EM profiling. Geophysics 77 (1), 1-14

Murray, A.B., Thieler, E.R., 2004. A new hypothesis and exploratory model for the formation of large-scale inner-shelf sediment sorting and "rippled scour depressions". Cont Shelf Res. 24, 295-315.

Niedoroda, A.W., Swift, D.J.P., Hopkins, T.S., 1984. Shoreface morphodynamics on wavedominated coasts. Mar. Geol. 60, 331-354

Niedoroda, A.W., Swift, D.J.P., Hopkins, T.S., 1985. The shoreface. In: Davis Jr., R.A. (Ed.), Coastal Sedimentary Environments. Springer, New York, pp. 533-624.

Pawlowski, G.A., 1985. Quantitative determination of mineral content of geological samples by X-ray diffraction. Am. Mineral. 70, 663-667. 
Pandian, P.K., Ruscoe, J.P., Shields, M., Side, J.C., Harris, R.E., Kerr, S.A., Bullen, C.R., 2009. Seabed habitat mapping techniques: an overview of the performance of various systems. Mediterr. Mar. Sci. 10/2, 29-43.

Park, S., 2004. Aspects of mangrove distribution and abundance in Tauranga Harbour. Environmental Publication 2004/16. Environment Bay of Plenty, Whakatane, New Zealand (40 pp.).

Parker, G., Lanfredi, N.W., Swift, D.J.P., 1982. Seafloor response to flow in a southern hemisphere sand-ridge field: Argentine inner shelf. Sediment. Geol. 33, 195-216.

Pickrill, R.A., Mitchell, J.S., 1979. Ocean wave characteristics around New Zealand. N. Z J. Mar. Freshw. Res. 13 (4), 501-520.

Rooper, C.N., Zimmermann, M., 2007. A bottom-up methodology for integrating underwater video and acoustic mapping for seafloor substrate classification. Cont. Shelf Res. 27, 947-957

Schwab, W.C., Baldwin, W.E., Denny, J.F., Hapke, C.J., Gyes, P.T., List, J.H., Warner, J.C., 2014 Modification of the Quaternary stratigraphic framework of the inner-continental shelf by Holocene marine transgression: an example offshore of Fire Island, New York. Mar. Geol. 355, 346-360.

Shepherd, M.J., McFadgen, B.G., Betts, H.D., Sutton, D.G., 1997. Formation, landforms and palaeoenvironment of Matakana Island, Bay of Plenty, and implications for archaeology. Science and Research Series 102. Department of Conservation, Wellington, New Zealand. (100 pp.)

Shepherd, M.J., Betts, H.D., McFadgen, B.G., Sutton, D.G., 2000. Geomorphological evidence for a Pleistocene barrier at Matakana Island, Bay of Plenty, New Zealand. N. Z. J. Geol. Geophys. 43 (4), 579-586.

Simarro, G., Guilléna, P., Puiga, M., Ribóa, M., Lo Taconob, C., Palanques, A., Muñoz, A Durána, R., Acosta, J., 2015. Sediment dynamics over sand ridges on a tideless midouter continental shelf. Mar. Geol. 361, 25-40.

Spiers, K.C., Healy, T.R., 2007. Investigation of sorted bedforms, Tauranga Harbour, New Zealand. J. Coast. Res. 353-357 (Special No. 50).
Spiers, K.C., Healy, T.R., Winter, C., 2009. Ebb-jet dynamics and transient eddy formation at Tauranga Harbour: implications for entrance channel shoaling. J. Coast. Res. 50 (1), 234-247.

Stein, D.L., Tissot, B.N., Hixon, M.A., Barss, W., 1992. Fish-habitat associations on a deep reef at the edge of the Oregon continental shelf. Fish Bull. U.S. 90, 540-551.

Stark, N., Coco, G., Bryan, K.R., Kopf, A., 2012. In-situ geotechnical characterization of mixed-grain size bedforms using a dynamic penetrometer. J. Sediment. Res. 82, 540-544. http://dx.doi.org/10.2110/jsr.2012.45.

Swift, D.J.P., Field, M.E., 1981. Evolution of a classic sand ridge field: Maryland sector, North American inner shelf. Sedimentology 28, 461-482.

Swift, D.J.P., Holliday, B., Avignone, N., Shideler, G., 1972. Anatomy of a shoreface ridge system, False Cape, Virginia. Mar. Geol. 12, 59-84.

Thieler, E.R., Foster, D.S., Himmelstoss, E.A., Mallinson, D.J., 2014. Geologic framework of the northern North Carolina, USA inner continental shelf and its influence on coastal evolution. Mar. Geol. 348, 113-130.

Trembanis, A.C., Hume, T.M., 2011. Sorted bedforms on the inner shelf off northeastern New Zealand: spatiotemporal relationships and potential paleo-environmental implications. Geo-Mar. Lett. 31, 203-214.

Trowbridge, J.H., 1995. A mechanism for the formation and maintenance of shore-oblique sand ridges on storm-dominated shelves. J. Geophys. Res. 100 (C8), 16071-16086.

Williams, A., Althaus, F., Schlacher, T.A., 2015. Towed camera imagery and benthic sled catches provide different views of seamount benthic diversity. Limnol. Oceanogr. Methods 13, 62-73. http://dx.doi.org/10.1002/lom3.10007.

Yoklavich, M.M., Greene, H.G., Caillet, G.M., Sullivan, D.E., Lea, R.N., Love, M.S., 2000. Habitat associations of deep-water rockfishes in a submarine canyon: an example of a natural refuge. Fish. Bull. U.S. 98, 625-641.

Zevin, L.S., Kimmel, G., Mureinik, I. (Eds.), 1995. Quantitative X-ray Diffractometry 372. Springer, N. Y. 